\title{
COMPETENCIAS SOBRE CAJAS DE AHORRO: LAS COMUNIDADES AUTONOMAS Y EL BANCO DE ESPAÑA
}

\author{
POR \\ Carlos Carrasco Canals
}

\begin{abstract}
SUMARIO: OBSERVACIONES EN TORNo A LAS COMPETENCIAS DE LAS COMUNIDAdes Autonomas EN RELACION CON LAS CAJAS DE AHORRO. La naturaleza jurídica de las Cajas de Ahorro. Incidencia, a través de atributos competenciales autonómicos, en las Cajas de Ahorro. La función normativa autonómica, en relación con las Cajas de Ahorro. La polémica sobre las Cajas de Ahorro fundadas en España por la Iglesia Católica. Las Cajas de Ahorro en una nueva dimensión, su carácter empresarial y posibles actividades: el futuro previsible. ALGUNAS PRECISIONES Y APRECIACIONES SOBRE EL PAPEL DEL BANCO DE ESPAÑA EN RELACION CON LAS CAJAS DE AHORRO
\end{abstract}

\section{OBSERVACIONES EN TORNO A LAS COMPETENCIAS DE LAS COMUNIDADES AUTONOMAS EN RELACION CON LAS CAJAS DE AHORRO.}

Varias razones obligan a tratar esta cuestión desde una perspectiva de simples "observaciones", pues la intención no puede ir más allá de hacer un catálogo cuestionable de sugerencias al respecto.

La primera y fundamental razón para esta decisión es la imposibilidad actual de decir la última palabra sobre la materia. La cuestión es abigarrada, compleja, muy matizada, atipica, observación hecha por el Tribunal Constitucional en la trascendental Sentencia no 49/1988 de 22 de marzo, que califica de atipicas a las Cajas de Ahorro, como Entidades de crédito que tienen este carácter. Nos encontramos en un mundo de atipicidades y singularidades, por ello la intención de cualquier estudioso sobre el tema en principio no puede sobrepasar esta inicial postura de hacer indicaciones, pues ofrecer soluciones, definiciones o elaborar doctrinalmente una teoria al respecto provoca con demasiada frecuencia dudas, vacilaciones, perplejidades y situaciones con frecuencia de difícil o imposible solución.

Otra circunstancia que avala la decisión de sólo proporcionar algunas observaciones, a manera de reflexión, se encuentra en el estado de la cuestión, existe una falta, que se puede calificar de orfandad 
y provoca un vacío para poder reflexionar, aportando soluciones, conclusiones hábiles, por lo cual se ha prescindido de todo aparato bibliográfico, escaso por demás, lo que justifica la ausencia de notas a pie de pagina, que sería lo obligado en este caso singular por falta de aportes doctrinales acreditados, para no actuar en el vacío. Esta coyuntura es apasionante para cualquiera, pues abrir brecha, iniciar un camino descoriocido en una tarea intelectual, es un acicate lo suficientemente sugestivo como para sentirse satisfecho en la elección de la línea de trabajo escogida. Pero como todas las cosas, la cuestiones son bifrontes, esta cara halagüeña tiene otra no tan satisfactoria, el peligro del desliz, de la trivialización, de la inseguridad y el riego evidente del desacierto. Por ello sin incurrir en un petición de principio, desde ahora nos disculpamos si hay osadía irreflexión o ligereza en los juicios y afirmaciones, siempre sometidos a revisión, o a mejor parecer en la opinión doctrinal o jurisprudencial.

La paradoja, incluso la entelequia es moneda de curso, forzoso en estas disquisiciones, acotadas en sus justos límites "Las Cajas de Ahorros y la competencias autonómicas sobre las mismas". Y esta cuestión producida sin solución de continuidad, se presenta habitualmente y casi hemos fraternizado con ella. Al principio de esta modesta investigación, sorprendía nuestro ánimo detectar contradicciones, posturas antagónicas, pertinaces posturas desviadas, sin razones aparente contumaces encastillamientos, sobre cuestiones ya dilucidadas y resueltas. Todo ello inicialmente sorprende, pero más tarde habitúa si la típica institución tradicional se califica por elementos atípicos en la actualidad, la paradoja, el contrasentido incluso en mucha de las rúbricas estudiadas hay un principio destructor insito y natural, aparece la entelequia. Es paradójico pero cierto sobre las instituciones de Ahorro y Crédito, los intermediarios financieros, Caja de Ahorros, la presencia siempre patente o latente, de elemento paradójico. Desde su nominación a su estructura, su tradición y actualidad, su funcionamiento y organización, su ánimo de singularidad e independencia frente a sometimiento, control e intervención. Un ejemplo explicativo y creo suficiente: se suelen Ilamar Cajas de Ahorros y Monte de Piedad, término el de "Monte" obsoleto, desusado y sin crédito coloquial hoy día. Sin embargo celosamente reivindicado, con idea de monopolio y uso en exclusiva por estas instituciones. La misma idea se encuentra en el término "fundacional", en el concepto de "obra social y benéfica" y tantas otras de la jerga profesional que nada o poco tienen que ver con la robótica, manipulación de unas líneas de actividad crediticia, en los negocios e intermediaciones financieras actuales y en los rasgos típicos, de unas instituciones modernas y " la pa$\mathrm{ge}^{\prime \prime}$ en nuestros días. 
Existen otras muchas peculiaridades, pero no vamos a insistir sobre ellas, sólo quede constancia de las mismas: la tradición, la confianza popular, la asequibilidad, la aparente falta de lucro, o de destino benéfico y social de los beneficios, la raigambre, la importancia en el ámbito local, la comunicabilidad, el beneficio y mejores condiciones en competitividad con otros intermediarios financieros el estímulo mediante premios, acicates, obsequios, etc. En fin un abigarrado mundo cordial en un frio y numérico panorama crediticio bancario y de seguros. Pues bien, en cualquiera de las circunstancia enunciadas se produce paradójicamente un ágil y moderno procedimiento una agresividad y competencia al uso, frente a estas ideas descritas que nada o poco tienen que ver y contrastan en polémica con la actividad y formulaciones de nuestros días.

No resulta una tarea fácil delimitar el estudio competencial de las Comunidades Autónomas en relación con los intermediarios financieros, Cajas de Ahorros. Inicialmente rehuimos de hacer conclusiones pero es necesario e indiscutible aportar juicios de valor y cierta consideraciones críticas indispensables, obligados por la naturaleza de la cuestión, justificados aunque no lo queramos por un devenir histórico, pues los esquemas organizativos, el funcionamiento, la gestión, en definitiva su ser y naturaleza se encuentra razonado en esa carga importante cual es su biografía, justificante de una manera y forma de obrar tradicional, enfrentada hoy con una cuestionabilidad término obligado, de concurrencia en un mundo de intermediación agresivo, competitivo y complejo condicionante de un futuro previsible con un actual momento cambiante.

Las Cajas de Ahorros al incidir territorialmente de forma acusada, son objeto de atención por parte de las Autonomías, éstas no pueden olvidar aspectos como los de la regionalización de inversiones instrumentos de fomento y desarrollo regional, cauce obligado para atenciones impulsadas a través de su obra social, importancia global en el crédito y ahorro regional, significado de estos agentes en el sector económico-financiero, etc. Por ello es de obligado cumplimiento la racionalización y ordenación de las correspondientes reflexiones en torno al tema, observaciones por supuesto ya expuestas en cada uno de los supuestos autonómicos, pero ahora reducidos a común denominador, generalizándose la problemática y con afán de claridad pues es la forma de ofrecer soluciones o al menos asimilarlas.

La tarea impuesta desde el inicio debía finalizar, sectorialmente, hacer un "excursus" sobre la interpretación habida en distintos órdenes (jurisprudencial, autonómico, local y estatal fundamentalmente), del sistema de distribución competencial nos hace enfrentar con las complejidades, entelequias, paradojas, variabilidad y ambigüedad 
aludidas. Por eso también a veces se olvidan cuestiones trascendentales y se significan quizá trivialidades, con el evidente riesgo de hacer anécdota de la categoría o a sensu contrario categorizar lo anecdótico.

Con las anteriores cautelas se propone un esquema, eventual susceptible de revisión, al hilo y tenor de tratamiento pormenorizado estudiado anteriormente, en donde se van a poner de manifiesto las cuestiones a nuestro entender fundamenteles en relación con el tema capital, el competencial, y cómo se ha ejercido el nivel autonómico, cuáles son sus posibilidades de futuro, cómo se ha llegado a la situación actual, nivel conflictual en su caso, caracteres de la cuestión, previa cuestionabilidad de la naturaleza juridica de las Cajas de Ahorros, análisis de las cuestiones planteadas doctrinal y jurisprudencialmente, la dependencia de estas Instituciones, los controles sobre las mismas y cuantos incidentes puedan plantearse directa o tangencialmente en torno a esta materia.

Una advertencia previa y necesaria, los temas de derecho público económico, hoy por sus especiales caracteristicas de actualidad, no llegan a tener un tratamiento ni científico doctrinal ni jurisprudencial convenido y si a esto le añadimos un plus, como el de que las Cajas de Ahorros son entidades en principio privadas, aunque su promotor sea público, se complica de forma evidente el panorama, ya que las problemáticas encardinadas en un tercer genus, en un gen hibrido, corvertientes, con una evidencia bifronte desconciertan, muestran evidencias contradictorias, la paradoja es moneda en curso forzoso, a veces se producen entelequias y desde luego muestran complejidad imposible de simplificación, pues se encuentra ínsita en su propia naturaleza. Todo ello condiciona, problematiza, hace el discurso y la lectura de estos temas abigarrada, frente a un simplismo cotidiano, de ejercicio, práctica diaria de la intermediación financiera en el crédito, ahorro y depósito, que demanda ideas claras, ausencia de complejidades, régimen de actuación con márgenes de seguridad, normativa simple y clara, apoyo en un régimen diáfano y transparente y cuantos posibles ingredientes necesarios para una gestión eficaz, puedan producirse y se urgen en el sistema financiero.

No se trata de una cuestión que llegue a ser una petición de principio, pero se aproxima a ella, por contraste y paradoja, al producirse en ocasiones un fuerte choque, un enfrentamiento entre la realidad $y$ el intento de su regulación, entre el ejercicio y la práctica y lo establecido, entre la concurrencia de factores determinantes y la determinación a diario de soluciones ignoradas, no previstas o regladas desde un distanciamiento de laboratorio y buenas intenciones, imposibles de ejecutar prácticamente. 
De ahí esas prevenciones pues ño nos acompaña un ánimo dogmático, ni tampoco una solución carismática, simplemente por defecto un intento de clarificar si estamos en oscuridad, sistematizar si es posible y colaborar, desde luego, en un importante sector demasiado huérfano de atención, aunque en apariencia filiado por toda clase de atenciones, quizás excesivas a nuestro entender.

Un elemental criterio ordenador nos impone, por reducción y generalización a epigrafiar las rúbricas generales sobre las cuales, en digresión, se han hecho procedentes, o en su caso no tanto, indicaciones.

\section{La naturaleza jurídica de las Cajas de Ahorro.}

Cuestión obligada, prius lógico, con el riesgo evidente de convertirse en el tema estrella de la cuestión, en el núcleo fundamental de cualquier investigación, culmen del estudio de cada institución. Con el riesgo de una crítica desde ahora aceptada, debemos manifestar la ponderación, a nuestro entender, con que se debe afrontar el tema, importante evidentemente pero no con tanta trascendencia como apariencia.

Se necesita evaluar justamente el significado e importancia de la naturaleza jurídica, pero rendir tributo y homenaje, por una pura especulación doctrinal, en un intento de dotar de valor absoluto a cuestiones de este talante, supone para nosotros un planteamiento equivoco. Además cada día sirven menos las posturas metodológicas maniqueas de si es pública o privada una cosa, un instituto, o una materia. Con frecuencia lo público y privado se aproximan, se confunden y no se puede hablar con propiedad, en casi ningún campo, desde luego en el jurídico no, de una distinción tajante. Lo público se privatiza y lo privado se publifica, si se nos permite el barbarismo verbal.

Tampoco debe olvidarse la poca o nula trascendencia que tiene, una declaración de principio sobre la naturaleza jurídica, realizada textualmente de forma positiva por la norma, ya que la realidad con frecuencia nos ofrece ejemplos numerosos, donde el derecho que se escribe no es el que se vive y la escasa trascendencia de esas aseveraciones. Para ser realistas y aproximarse lo más posible a la verdad, si se entiende ésta como la realidad, habrá de examinarse, con datos concretos y evidentes, cual es la naturaleza de aquélla prescindiendo de declaraciones, formulaciones doctrinales, encasillamientos lógicoformales, con frecuencia elementos desvirtuadores y confusos, sólo justificados en especulación. A todo esto se añade un elemento importante, ingrediente definidor, en ocasiones olvidado, cual es la obsolescencia de las definiciones o las tipificaciones con años de tradición, ni 
lo público ni lo privado son hoy lo mismo que en el siglo XIX ni las Cajas de Ahorro de hoy se parecen en nada a las benéficas Instituciones, montes píos, depositarias de un ahorro popular de clases poco favorecidas, de antaño.

Con todas estas alusiones preliminares se intenta ahora una tipificación por contraste de unas instituciones atípicas en el tráfico mercantil y en la intermediación financiera:

1. Carácter no mercantil de las Cajas de Ahorros. Sobre este tema lo suficientemente debatido por la doctrina y jurisprudencia del Tribunal Constitucional incluso no se va a insistir pues el razonamiento se encuentra en la definición que se da en la disposición (Decreto de 14 de marzo de 1933, Gaceta del 17, modificada por Decreto; de 3 de julio, BOE de 11 de agosto), que regula las Cajas Generales de Ahorro Popular, donde en su art. $2^{\circ}$ da una definición de aquéllas hoy Cajas de Ahorro al decir: "Se entenderá por Cajas Generales de Ahorro popular las instituciones de Patronato oficial o privado exentas de lucro mercantil". Se subraya este carácter pues la norma no ha sido derogada y en la actualidad y se reproduce. Cualquier reciente Estatuto de Cajas de Ahorro, por poner un ejemplo reciente y citado en el texto, el Decreto 11/1987, de 5 de enero, del Presidente de la Comunidad Autónoma de Canarias, aprueba los Estatutos y Reglamento Regulador de la Caja Insular de Canarias y en el Anexo, donde se publican los Estatutos al determinar en el Tít. I: Fundación, naturaleza y régimen legal. El art. 1을 de la Caja Insular de Ahorros de Canarias como "...institución benéfico-social, exenta de lucro mercantil. " (el subrayado es nuestro).

Por supuesto esta tipificación tiene connotaciones tradicionales, pudo ser correspondiente en su momento, hoy la realidad es otra, se ha producido lo que anunciamos antes, en cuanto una declaración puede ajustarse a la realidad en su momento y después desnaturalizarse, como es éste el caso. Nadie duda hoy del carácter de intermediario financiero de las Cajas de Ahorro, cuyo objetivo es si no el lucro por el lucro, tal vez sea el binomio lucro-obra social, o medio para conseguir esos fines benéfico-sociales impregnantes siempre en este tipo de instituciones.

2. Carácter fundacional de las Cajas de Ahorro. Que las Cajas de Ahorro son una fundación es una nota tipificadora, en la cual coincide la doctrina, la jurisprudencia y el derecho positivo. Sin embargo consolidada a través del tiempo la naturaleza jurídicofundacional de aquéllas, por darse las notas tipificadoras y elementos de una fundación común: fin, patrimonio, personalidad, 
afectación de bienes patrimoniales, etc. , sin embargo esta nitidez se oscurece y no encajan como modalidad, diríamos es atipica, en ninguna de las formas acuñadas, primero en la llamada "fundación benéfica" pues si tiene notas que le aproximan a las instituciones de beneficencia, otras las distancian sobre todo la obtención de beneficios netos, inversiones aunque sean sociales, estimulación del ahorro, etc.

\section{Las Cajas de Ahorro; en una nueva dimensión, su carácter em- presarial, sus nuevas y posibles actividades: el futuro previsi- ble.}

A pesar de las retóricas manifestaciones de la Sentencia 49/1988, sobre la delicadeza de la actividad de las Cajas de Ahorro, la conexión entre la función y el riesgo, que no debe entrar en el concepto de empresa privada, de su falta de correspondencia con la empresa y el precepto constitucional de la libertad de empresa, que la transformación sufrida ha modificado su estructura como personas jurídicas y toda la argumentación contradictoria, y no es nuestra la expresión sino del voto particular del Magistrado del Tribunal Constitucional Sr. Diez-Picazo y Ponce de León. Pues bien todo ello nos reconduce a reflexiones.

Negar el carácter de empresa a las Cajas de Ahorro, es una declaración no afortunada y el tiempo y la realidad social se encargará de desmentir, a pesar de ampulosos pronunciamientos.

Utilizar un parámetro de la finalidad de lucro como índice discriminador para atribuir o no condición empresarial es invertir los términos y resolver por atipicidad es no resolver, condicionar la aplicación del art. 38 de la Constitución Española que garantiza la libertad de empresa, atribuible sólo a organizaciones con finalidad de lucro, lo cual es sorprendente.

El principio de libertad de empresa reconocido en el art. 38 de la Constitución Española vigente, protegido y garantizado por los poderes públicos deviene en autonomía organizativa, no respetada por la LORCA, sobre todo en aquellas Cajas de Ahorro de origen privado o de la Iglesia, pues las fundadas por las Administraciones públicas pueden merecer la consideración de "Empresas públicas" y no es ahora momento de su tipificación.

La traslación de poderes, en frase del Magistrado del Tribunal Constitucional disidente en la Sentencia 49/1988, de la gestión de las Cajas al sector público, conservando en régimen juridico patrimonial sin afectar, supone incorporar dentro de sus Organos Rectores, 
importante cuestión pues ellos detentan la dirección de la Entidad, una posición dominante sobre todo a las Corporaciones Locales. Esto por vía indirecta, al señalarse cómo se deben nombrar y cual es la representación por cuotas, los órganos directivos de gestión una peculiar especie de municipalización de las Cajas de Ahorro, hasta la LORCA con carácter eminentemente privadas.

Si la libertad de empresa reconocida constitucionalmente supone, como hemos dicho posibilidad de autoorganización y decisión y no sólo libertad de fundación de la misma se ha producido un trasvase de la titularidad, sin retocarse ni afectarse la Institución.

Donde parece se ha producido, para nosotros la desviación en el juicio constitucional estudiado, es al filiar la idea de empresa con el riesgo de la gestión y en el supuesto de las Cajas de Ahorros por motivos peculiares, el carecer de propietarios entre otros, le hacen ser "atípicas", definición poco relevante en derecho, como hemos visto.

El criterio teleológico finalista: el del objetivo fundamental, dedicar sus beneficios a la obra social, matizan para el Tribunal Constitucional, al aparecer el interés público, nuevamente su atipicidad y no poder ser consideradas empresas.

Afirmamos la naturaleza de las actividades a que la empresa se dedique, en el supuesto de las Cajas de Ahorro su finalidad no lucrativa, no desnaturaliza ni modifica su estructura como personas jurídico privadas. Si no habría que estudiar también en el supuesto frecuente de instituciones bancarias con fundaciones y obras sociales importantes, que a lo mejor afectan parte de su gestión y beneficios a las mismas para su sostén y alimento, en qué parte no son empresas y esta atipicidad singular cómo les afecta en cuanto a su naturaleza. Naturalmente el argumento es por reducción al absurdo contemplado.

Es evidente los poderes públicos no deben de abstenerse de intervenir en las Cajas de Ahorro, entre otros motivos por la función social que desempeñan, imponiéndose determinados deberes, garantes de una gestión correcta, incluso con menor riesgo, como son la forma de sociedad impuesta a las entidades bancarias. Pero esto es una cosa y distinta lo realizado: traslado al sector y agentes públicos de los poderes de decisión y gestión.

En definitiva no se puede confundir la naturaleza y la estructura, pues el carácter de las actividades no trasciende estructuralmente $y$ menos para configurarlas a las Cajas de Ahorros de atípicas.

Posiblemente y zanjada antes, la reflexión sobre el carácter y naturaleza de las Cajas de Ahorros es volver ahora sobre el tema y estudiado, pero como presupuesto necesario era imprescindible hacerlo pues esa referida nueva dimensión de las Cajas de Ahorros a partir de ahora, debe contemplar la realidad desde la cual se consideran 
y cómo presumiblemente estos moldes han de saltar, no en pro de una pulverización, por motivos aleatorios sino en sustancia por necesidad de adecuación social al margen de definiciones imprecisas y justificaciones el nuestro entender triviales.

No es necesario contar con una especial sensibilidad, ni ser experto en organización, funcionamiento y administración de estos peculiares intermediarios financieros, para observar su aproximación e condiciones de competencia, en plano similar si no igual con otros agentes bancarios.

El carácter típico, ancestral del "empeño" ser "Monte", el préstamo característico de las Cajas de Ahorro permanece como reliquia, pese a su importancia y ser resucitado como novedad en determinados momentos, generalmente críticos. Sin embargo el crédito en términos actuales es cada día más importante, por supuesto el depósito, en general la actividad conocida con el nombre de bancaria, es lo presente.

Si las Cajas de Ahorro no quieren entrar en obsolescencia, como ocurrió en un momento determinado en nuestro país, reaccionando y compitiendo a posteriori y situándose en vanguardia en el tráfico monetario y en la gestión bancaria, es presumible en el futuro habrán de abordar retos ahora incipientes y sectorializados en varios aspectos: seguros, pensiones, asistencia y prestaciones complementarias en orden a la Seguridad Social, intervención en el mercado de valores con mayor énfasis que el actual, agrupación de Cajas no sólo en Federación Autónoma o Nacional, sino al menos a nivel de Mercado Común Europeo, internacionalización de los negocios y participación en el tráfico, nuevas fórmulas de depósitos de cuentas, participación a través de medios hoy generalizados de tarjetas de crédito, expansión de las cuentas y nueva configuración de las actuales denominadas "especiales", superar la actual y tradicional "cartilla" y una nueva concepción del Ahorro y por supuesto para identificarse conservar el logotipo, sobre todo en denominación de Cajas, pues este hallazgo nominativo, tan familiar y entrañable como elemento psicológico es atractivo y si se maneja bien, es un elemento de captación importante.

El elenco de cuestiones, ahora simplemente insinuadas, no se agota con las indicaciones anteriores y cada una de ellas y otras posibles, pueden plantearse y entendemos deben fundarse en estudio, reflexión e investigación.

Si los medios de gestión indudablemente informatizados han transformado la intermediación financiera, este soporte va a demandar un cambio. Parece una contradicción pero así es, la naturaleza de las Cajas, evidentemente empresas y fundaciones y sin ánimo de lu- 
cro aparente, entendiendo lucro a la manera tradicional, habrán de transformarse y adquirir nuevas señas de identidad para competir en un mercado cada día más amplio, más transparente, más democrático, más funcional y todos los plus que se quieran añadir.

Entendemos el último reducto tradicional es la obra social, hoy concebida como cosa distinta y tal vez variable con el transcurso de los años. A partir de esta idea se puede operar una gran tarea transformadora y en base a esa finalidad, intervenir con trasparencia y en posición para tener reservada, ya desde el inicio, de una cuota importante en el mercado y en la economía de nuestro tiempo.

Las Cajas de Ahorro en un futuro inmediato habrán de superar ideas trasnochadas, aunque respetables, impregnar de secreto, de cautela, confidencialidad mal entendida, todo un tráfago mercantil es no estar al día.

Monopolizar gestión y parcela de poder, en un reparto de un mundo económico cada vez más compartido, es actuar de espaldas a la realidad, pues hoy se predica al menos la solidaridad, la colaboración, la coparticipación, el volumen mínimo para actuar y de ahí fusiones, concertaciones, Convenios, Acuerdos, etc., para poder competir en un nivel de garantía y eficacia.

Por todo lo expuesto en reflexión y observación, sin ánimo dogmático, es necesario e imprescindible reaccionar al estimulo presente, sintoma de un futuro fácilmente previsible, donde el cambio, la flexibilidad, la adaptación, la solución inmediata se impone. Lo cual no significa en manera alguna desorden o confusión, simplemente selección de aquéllos que sepan, puedan y quieran ponerse al día y en previsión futurible ordenar los mecanismos precisos para responder a una demanda cada día más exigente y a unos competidores cada dia más agresivos.

Resucitar fórmulas decimonónicas, hacer una biografía histórica de las Cajas de Ahorro, estudiar sus componentes y estructura, su finalidad y objetivos, declarar son instituciones que responden a situaciones superadas es reaccionar tarde y sin congruencia. Es verdad responden a todo lo antedicho, pero es menos cierto son agentes, intermediarios, protagonistas, peculiares desde luego, con su especial fisonomía y carácter pero necesitados de contraste y evaluación en una vida donde alusiones a criterios o situaciones superadas de nada sirve, no pueden justificar su actuación en lo que fueron en el pasado o su filantropia contrastada históricamente, deben ser respuesta en las condiciones actuales y permeables a futuras situaciones.

Por supuesto no es momento sino de reflexión y apunte, destacando aquellos aspectos y peculiaridades más significativas y no todos ni las más importantes, una descripción detallada, llegando el pormenor en ocasiones a ser abusivo, se encuentra en el texto. 
A efectos didácticos y de claridad en la exposición vamos a agrupar las cuestiones al respecto.

1. Preocupación por reivindicar una parcela de poder e intervención por todas las Comunidades Autónomas, en relación con las Cajas de Ahorros.

La intensidad es gradual según el tipo de Comunidad Autónoma, generalmente las de techo competencial superior, las históricas y asimiladas, intentan, manifiestan su voluntad y controlan, dirigen, intervienen, acaparan, inciden, en definitiva entienden es una parcela de ejercicio a la cual se debe dar una regulación desde legal a reglamentaria, sin respeto por la jerarquía normativa, pero con gran incidencia.

Este fenómeno se traduce en una cierta desigualdad de trato, según el espacio físico en que la Caja de Ahorros se ubique. Evidentemente hay diecisiete regímenes distintos, algunos idénticos, otros similares y en el extremo diferentes.

Obviamos un problema conexo, manifestado antes, sobre el concepto y alcance de la noción de bases constitucional, pero necesariamente hemos de hacer alusión, pues del reparto que se haga Estado/Comunidades Autónomas va a salir el producto: titulo competencial autonómico, habilitante para incidir sobre el sujeto Cajas de Ahorro.

Las Cajas de Ahorros reciben diversos impactos, que como directivas determinan su funcionamiento, gestión, administración y funciones. Y la carga que soportan proviene de dos fuentes, la una próxima el nivel autonómico, la otra más alejada, pero no menos coherente, la autoridad del Estado, de la Administración Ilamada Central, ejercida generalmente por un intermediario: el Banco de España.

No son sutilezas detrás del ejercicio competencial autonómico hay un ingrediente político importante. Las cuestiones económicas y ésta lo es, se significan y modulan políticamente. Temas como los de participación, representación, regionalización y otros muchos responden a criterios políticos, están en programas de partido y no digamos ya la cuestión cumbre, estrella en las actuaciones de nacionalización o privatización.

Por todo lo expuesto la cuestión es muy sensible y afecta a las Comunidades Autónomas en tal dimensión y grado que gran parte de su política económica regional, la instrumentan por medio de las Cajas de Ahorro. Estas son instrumentos, interlocutores válidos, en ocasiones dóciles, para incidir, como importantes protagonistas en una trascendental cuestión: el bienestar, la prosperidad, el nivel de vida, etc. 
Evidentemente con una cuota de participación, nada desdeñable de otra parte.

De aquí los problemas sobrevenidos hay actitudes autonómicas enfrentadas lógicamente si una Autonomia recaba para si cualquier actividad de intermediación realizada por las Cajas de Ahorro en su delimitación territorial, se enfrenta con otra que sólo reivindica intervenir en aquéllas cuya sede social o central se ubique en su territorio. No es lo mismo "operar" que "radicar", los términos se utilizan usualmente y la intención es recabar para sí el ahorro, la inversión y cualquier manifestación en el sector económico regional, para evitar generar riqueza en un sitio y trasladarla después a otro, con lo cual se hace un flaco favor a la economía y al mercado financiero autonómico, autóctono, originario, para trasladar beneficios a otra Autonomía, por los más singulares y peculiares motivos, ahora no examinados.

2. Las rúbricas habituales de los títulos competenciales ejercidos, se hacen bajo títulos de propias, exclusivas, compartidas, concurrentes, de ejecución, desarrollo, reglamentación, etc. No es hora pues se ha hecho ya, del examen pormenorizado y casuístico en cada supuesto autonómico.

Si se debe significar la riqueza producida y la instrumentación tan distinta, utilizada para conseguir el mismo fin.

Son temas de implementación, pero con trascendencia. Un abandono, una dejación de atribuciones competenciales sobre la materia puede traer consecuencias y resultados no queridos, a pesar de la voluntad política, dada por supuesta, de que cualquier Autonomía quiere lo más y lo mejor para su Región.

Aunque parezca baladi, la perfección técnica, la instrumentación adecuada, diríamos incluso la imaginación inteligente para modular las competencias atribuidas, con un apoderamiento racional puede potenciar y propiciar niveles de desarrollo económico regional insospechados.

Una evidencia es que las Cajas de Ahorro, quizá por tradición, por gestión y profesionalidad, por haber sabido situarse en el concierto económico en la primera línea, por adhesión popular un"awiamento" evidente como es la confianza, por su número, arraigo y todas esas razones aparentemente no evaluables, dimensionan a estas instituciones y más a nivel local, con tal fuerza que compiten en situación de privilegio y se contemplan con fraternidad y no con cierto sigilo y prevención, como ante otras instituciones bancarias.

Desde su denominación "Cajas", mucho más próxima y familiar, las alusiones al "Ahorro" e incluso al empeño, "Monte de Piedad", 
han lanzado un mensaje, si se quiere anacrónico hoy, pero inteligentemente utilizado (los logotipos modernos son un ejemplo), para contribuir a esa importancia y protagonismo denunciado.

Todo esto contribuye a que los Ejecutivos y las Administraciones Autonómicas se preocupen por el financiamiento, fomento y gestión de las Cajas de Ahorros, con mayor o menor fortuna, depende del tacto de los Parlamentos o en su caso de las Administraciones de las Autonomías.

Los resortes para dirigir la actuación de las Cajas, amparados por lo más diversos títulos competenciales y bajo formas desde Ley hasta Acuerdós, Circulares, Instrucciones y Convenios (legislación menor), son muy numerosos pero la prudencia debe presidir esta actuación para no asfixiar ni encorsetar una actividad hasta la fecha desenvuelta con agilidad y pacifica convivencia.

La labor de incentivación, mejor que el tradicional fomento, debe estar presente pues cada día las normas en el campo de sector económico son menos imperativas más indicativas, más propiciadoras aunque en su caso y en menos ocasiones de las aparentes, han de ser coercitivas, cogentes, determinantes e imperativas.

Las anteriores observaciones se hacen al hilo de la situación descrita en el texto, de cómo y en cada caso se ha actuado. Si se hace dejación competencial malo, si se excede y extralimita tal vez peor, si se pondera, si se estimula, si se coordina la actividad directiva autonómica se marida con la de las Cajas y produce magníficos resultados beneficiosos para esta unión.

3. Soluciones en torno al ejercicio competencial autonómico en relación con las Cajas de Ahorro.

En este sector no hay soluciones carismáticas ni tampoco de valor universal. Tal vez los criterios como reflexión deben tener el mismo o similar talante pero no más.

En primer lugar conviene, en el organigrama de cada Comunidad Autónoma, atribuir a una unidad de cierta relevancia, por ejemplo Dirección General o asimilada, la responsabilidad de estos temas.

Somos enemigos de los universos burocráticos y en la inteligencia del riesgo de una burocratización, hacemos estas precisiones. Decir debe haber una atribución clara, precisa y coherente de responsabilidad en la materia Cajas de Ahorro, no significa exclusiva o excluyente postura. Es imprescindible una clara identificación, el poder dirigirse a un órgano concreto, no importa se titule genéricamente "ordenación del crédito, banca... ", pues si dentro del Ejecutivo regional 
hay concurrencia de Consejerías o Departamentos implicados en el tema, y nadie tiene atribuido en específico el problema, los resultados tendrán una dudosa eficacia, por imprecisión, reenvío de una a otra unidad responsable, por corresponsabilidad en la resolución, por incidencia en las soluciones, todo ello en detrimento de una clara, eficiente y eficaz gestión.

Se propugna pues una identificación de los órganos gestores autonómicos responsables, con incidencia en la materia: Cajas de Ahorros, con un código o manual de instrucciones concreto y claro, para la necesaria fluidez en las relaciones y transparencia en la gestión, todo ello en beneficio de un principio el de economia y subsiguientes de celeridad y eficacia que deben presidir toda la actuación no sólo en la Administración sino en cualquier tipo de gestión.

4. El sistema de reparto competencial supone la caracterización del denominado "Estado de las Autonomías", pero este esquema lógico formal simplemente enunciado no explica por si solo, como deslinde material, la realidad. Hay otros elementos y uno de los más importantes es el de la capacidad financiera de los Entes autonómicos para ejercer y posibilitar dicho esquema competencial. Ahi intervienen con gran incidencia las Cajas de Ahorros, genuinos intermediarios financieros, con la caracterización y peculiaridades antes descritas.

Unas evidentes observaciones al respecto de toda esta viva problemática competencial, para aplicar en el sector económico-financiero cualquier insinuación, observación, intento de solución o propuesta en la actuación:

- nuestro sistema competencial prevé un doble juego y funcionamiento, a partir de un principio unitario, que no es otro que el dispositivo, significando éste la atribución de competencias por las Comunidades Autónomas asumidas en sus Estatutos, de ahí nuestra machacona insistencia en describir en cada uno de los supuestos las alusiones estatutarias respecto a la materia Cajas de Ahorro. Por simple puesta en práctica de este principio dispositivo las competencias no asumidas en un Estatuto, y se dan casos en nuestro supuesto, son de titularidad estatal, con una cláusula residual favorable al Estado.

- las Comunidades Autónomas de primer grado, de acceso cualificado, las históricas y asimiladas, pueden incluir en sus Estatutos competencias en toda clase de materias, excepto las exclusivas del Estado descritas en el art. 149.1 de la Constitución.

- las Comunidades Autónomas de segundo grado, de acceso no 
cualificado o diferido en la terminología de algún sector doctrinal, pueden asumir competencias en las materias determinadas en el art. 148.1 de la Constitución, el apartado 13 sobre "fomento del desarrollo económico" es la referencia obligada, como hemos visto. Naturalmente el transcurso de 5 años y la reforma estatutaria, obligada constitucionalmente, supone una ampliación del ámbito competencial.

- existe una posibilidad de ampliación, fuera de los Estatutos, de las competencias, que no es una delegación legislativa a la manera del art. 82 de la Constitución, sino la derivada del art. 150.1 habilitadora respecto de las Comunidades Autónomas para dictar normas legislativas en el marco de los principios fijados por una Ley del Estado. Además de la posibilidad de la transferencia, mediante Ley Orgánica que contempla el art. 150.2 de la Constitución que posibilita la transferencia de facultades de titularidad estatal, a nuestro objeto es interesante todo lo que incida respecto del 149.1.11ㅇ y $13^{\circ}$ fundamentalmente, pues ahí aunque no nominadas expresamente, como se ha denunciado, están las Cajas de Ahorro.

- también existen posibilidades constitucionales de minoración competencial frente al aumento contemplado. Nos referimos al supuesto de la Constitución Española del art. 150.3 claro supuesto, con requisitos naturalmente, de armonización de las disposiciones normativas de las Comunidades Autónomas. EI Tribunal Constitucional entiende que este precepto es una norma de cierre del sistema de reparto competencial, debiéndose utilizar sólo cuando no se tengan otros cauces constitucionales, para garantizar la armonización.

- después de declarar la ausencia de normación y alusión a las Cajas de Ahorro, constitucionalmente y sólo por vía de deducción, incluidas en el término "banca" (149.1.11) ), el precepto configurador de la tipología competencial a partir del art. 149.3 de la Constitución Española es una norma no de atribución competencial, como parece, sino germen de tensiones, conflictos y polémica.

- la materia Cajas de Ahorro al ser compartida, en la terminología usual, determinando las bases el Estado y dictando normas de desarrollo las Comunidades Autónomas, nos sitúa en una disyuntiva excesivamente prolija en matices, suficientemente polémica como para abandonar la discusión después de las observaciones pertinentes realizadas en el texto, donde se recoge nuestra opinión y la doctrina jurisprudencial del Tribunal Constitucional. 
- en el sector objeto de estudio, el económico-financiero, con el tratamiento discriminado de los sujetos, agentes financieros, intermediarios peculiares las Cajas de Ahorro, las competencias ejecutivas, o de ejecución son importantes. La distribución competencial al respecto, realizada por la Constitución, no aparece y reenvía a los Estatutos esta tarea, para que sean las Comunidades Autónomas las que estatutariamente determinen y asuman las estimadas pertinentes, opción a nuestro entender poco feliz, pues supone no ofrecer un modelo, además de confundir. No hay una distinción entre la ejecución autonómica de normas estatales y de las propias normas autonómicas. Al ejecutarse la normativa estatal y en esta materia es frecuentísimo el supuesto no debe suponer se reconozca al Estado una actividad de vigilancia y control de esa ejecución, con un control genérico e indeterminado, con dependencia jerárquica, es a nuestro entender reconocer al Estado como verificador de una actividad, lo cual puede dar lugar a las actuaciones de controles, que sobre las Comunidades Autónomas tiene y están establecidos constitucionalmente.

- la transferencia de competencias previstas constitucionalmente en el art. 147.2, no suponen normas, los Decretos de transferencias, atribuidoras de competencias, pues es el Estatuto de Autonomía el instrumento idóneo. Aquéllas lo que realizan es la transferencia de los medios necesarios para el ejercicio.

\section{La función normativa autonómica, en relación con las Cajas de Ahorros.}

El tema del ordenamiento jurídico, del régimen jurídico autonómico en relación con las Cajas de Ahorro es interesante y revelador. De ahí que en cada uno de los casos, en las 17 Autonomías españolas hemos dedicado una parte, a veces fundamental a examinar cronológicamente esta producción, normativa, pues es un índice revelador $y$ ofrece una panorámica aproximativa de la realidad del cómo se entiende la cuestión en cada caso y el "cuantum" nos significa de alguna forma el nivel de preocupación por estos temas.

Una visión global ofrece el siguiente panorama:

Se puede hacer una clasificación por Comunidades Autónomas atendiendo al nivel de regulación legal; unas como Cataluña y Galicia cuentan con una Ley Autonómica, General de Cajas de Ahorros; otras entre las que se encuentra como ejemplo típico y 
reciente Murcia, mediante Ley adapta sus previsiones a la LORCA, después de la Sentencia del Tribunal Constitucional de 22 de marzo de 1988, sentencia 49/1988, que resuelve sobre la constitucionalidad de la Ley 31/1985, de 2 de agosto, en siglas LORCA, de regulación de Normas Básicas sobre Organos Rectores de las Cajas de Ahorro; otras adaptan mediante Decreto sus disposiciones a esta Ley, antes y después de resuelto el recurso de inconstitucionalidad citado. Por último Comunidades Autónomas pioneras en preocupación y regulación sobre la materia, como Galicia y Cataluña, modifican este año de 1989 sus Leyes Generales de Cajas de Ahorros, como consecuencia de las Sentencias 48 y 49/1988, de 22 de marzo, del Tribunal Constitucional. La Ley 6/1989, de 25 de mayo, de modificación de la Ley 15/1985, de 1 de julio, de Cajas de Ahorros de Cataluña, vuelve a ser impugnada por el Gobierno de la Nación, por enfrentamiento con la Ley Reguladora de las Bases de Régimen Local 5/1985, de 2 de abril, que establece unos "quorum" distintos sobre el Pleno de las Corporaciones Locales, a los exigidos en el añadido del art. 17, ap. b, párrafo cuarto de la nueva Ley. Hay Comunidades Autónomas cuya regulación es muy escasa, de escaso valor formal, con normas de rango interior, lo comunmente llamado legislación menor, que atienden al tema a veces tangencialmente. En el año 1990, la Comunidad Autónoma Valenciana por Ley 1/1990 de 22 de febrero y la de Castilla-León por Ley 4/1990 de 26 de abril, así como la de Canarias por Ley 13/1990 de 26 de julio regulan de forma general las Cajas de Ahorro. Cantabria mediante Ley 1/1990 de 12 de marzo regula los Organos Rectores.

El panorama pues es variopinto en todos los sentidos desde los instrumentos normativos hasta las parcelas reguladas, incluso se observa un denominador común: todos los Estatutos de Autonomía aluden a la voz "Cajas de Ahorro", con ortografía distinta, en singular o plural, con otras instituciones o independizando su trato, pero se detecta una preocupación generalmente sentida aunque cualitativa $y$ cuantitativamente el trato sea diferenciado, como se ha subrayado en el texto de este estudio.

En cuanto a precisión técnica, pureza en el tratamiento de la materia, definición clara de los posibles apoderamientos competenciales, atribución y responsabilidad orgánica con definición de los gestores e intervinientes en el tema, hay una multiplicidad de soluciones de las más variadas formas, hemos tenido ocasión de mostrarlo aunque sólo sea a título indicativo. 
En cuanto al ámbito, a la extensión de la acción ejercida los títulos, las atribuciones, las delimitaciones se hacen prolijas, lo habitual es referirse al domicilio social, a las que radiquen, a las que tengan su sede, aquéllas con la Oficina Central o Principal en el territorio regional de la Autonomía. Pero ello no impide soluciones más generosas, ambiguas, extensivas, como la expresión de "que operen" utilizada por alguna Comunidad Autónoma como Castilla-León, donde la simple actividad, prescindiendo de la radicación de la Institución, les faculta para intervenir. Las Cajas de Ahorro significadas por su domiciliación, incluso por su nomenclatura y logotipo, superan esta concepción raíz y la actividad, el funcionamiento, la influencia, la intervención en el tráfico financiero en una Región determinada, con criterios objetivos, puede suponer sometimiento y regulación por la forma de entender la Autonomía los limites competenciales, que le están atribuidos. Evidentemente esto se hace no estatutariamente, pero sí en la normativa y con ropaje jurídico de la más variada apariencia, en su caso en la normativa menor, Circulares, Instrucciones, Acuerdos,

Convenios, etc. , es frecuente observar esta vis expansiva en algunos supuestos.

Otro contraste, pues la paradoja están siempre presente al estudiar la casuística, es que sin un fundamento racional se producen regulaciones minuciosas, pormenorizadas, exhaustivas y totales en algunos casos y ausencia o abandono regulador en otros. Podría suponerse esto es consecuencia de la importancia en la zona de estas instituciones de crédito y ahorro, de préstamo e inversión, de función social y benéfica de trascendencia económica, pues tampoco responde a la realidad y la reacción normativa no es a menudo consecuente con esta proposición, aunque en ocasiones sí se observa esta correlación.

Otro tema común en el tratamiento autonómico normativo es el de filiar las Cajas de Ahorro al fomento, al desarrollo económico a paliar crisis, a temas puntuales como el desempleo, la vivienda, el apoyo a la pequeña y mediana empresa, a sectores comerciales, industriales, agrícolas o ganaderos. Parece como si estuviese en ellas una solución de bienestar y progreso, de modernización y solución planificada a nivel económico regional.

De otra parte hay una preocupación general por conseguir una reinversión de beneficio regional, la regionalización de la riqueza obtenida en la gestión y función de las Cajas, es común y sentida por todas las Autonomías, de ahí una abundante, en ocasiones no tanto, regulación normativa, que tiende a un objetivo muy claro, la captación de capitales en la jurisdicción autonómica no debe situarse después en otra Comunidad Autónoma, se debe utilizar como instrumento, 
motor y palanca del desarrollo regional. Es frecuente la normativa sobre regionalización de inversiones en la mayor parte de las Comunidades Autónomas.

Una evaluación, incipiente desde luego y sometida a revisión y critica, del problema de la regulación sobre las materias directamente relacionadas con las Cajas de Ahorro, a nivel de Autonomía, nos conduce a afirmar debería tenderse a una cierta homogeneización, que no uniformidad en el trato por las peculiares características regionales de las Cajas, en determinadas regiones patrocinadas por la Iglesia Católica, en otras fundadas por Entes Públicos, en algunas fruto de empresas en su día más o menos filantrópicas, en fin un variado panorama muy significativo, que se debe tener en cuenta, pero ello no impide, partiendo de la norma estatutaria en cada supuesto, en primer lugar llegar a un nivel de competencia material similar, por la vía que se quiera arbitrar, a partir de ahí una norma general adaptada a la legislación básica estatal, desarrollada en cascada con una normación de rango jerárquico menor, pero ponderada en cuanto a su perfección técnica, posible jurídico y adaptada a la realidad socioeconómica del lugar, región o Comunidad Autónoma.

El derecho regulador de las Cajas de Ahorros es atípico, en primer lugar por la atipicidad de las Instituciones que regula, pues asi les ha calificado la jurisprudencia constitucional, si bien entendemos calificar de atípica a la institución no es decir nada o muy poco, con ello se obvian problemas pero el real es definirlas y comprometerse con su regulación. Pero hay un ingrediente auténtico, que no puede olvidarse, su especial carácter, con una actividad crediticia muy importante y con trascendencia, por lo cual la prudencia debe imperar, evitando innecesarios riesgos asumidos en determinado sector empresarial, pues ello podría comprometer no sólo a la propia empresa, sino a la economía en este caso regional.

\section{La polémica sobre las Cajas de Ahorros fundadas en España por la Iglesia Católica.}

Supuesto puntual y sobre el que debemos hacer algunas reflexiones, al haberse planteado en conflicto, ante el Tribunal Constitucional en la Sentencia 49/1988, de 22 de marzo, sobre la situación actual.

Lo importante es que el Tribunal Constitucional elude resolver el problema de la disposición adicional segunda de la LORCA respecto a su inconstitucionalidad y el art. 96.1 de la Constitución Española.

Pues la Santa Sede firma con el Estado Español un Acuerdo sobre "Asuntos jurídicos" cuyo Instrumento de Ratificación es firmado el 3 
de enero de 1979 (BOE del 16 de diciembre) y a juicio de los recurrentes (Don José María Ruiz Gallardón y 54 Diputados en recurso de inconstitucionalidad num. 991/85 contra la totalidad de la LORCA y alternativamente contra varios preceptos de la misma, uno de ellos el citado) habia una contradicción. La solución del Tribunal Constitucional es de que el examen no le corresponde y no procede entrar en el fondo de este motivo alegado, ya que no puede considerarse vulnerado el art. 96. 1 de la Constitución Española.

No vamos a reproducir la argumentación, incidencias y situación provocada, pero se manifiesta la falta de solución, es una situación pendiente, germen de posibles y futuras polémicas, para llevar a la jurisdicción competente los posibles conflictos por antinomia entre dos normas del ordenamiento interno, que no interior como dice el fundamento jurídico 14, penúltimo párrafo de la Sentencia aludida.

Se puede calificar de hábil, pero no de feliz ni acertada la solución del Tribunal Constitucional, pues dejar pendiente algo es propiciar un foco de futuras contiendas, el no resolver resolviendo, pues así se hace, está en contradicción con el verdadero sentido informador de la soluciones en juicio.

Se ha producido un enfrentamiento entre la Santa Sede y el Estado Español, por cierto no es aquélla, ni siquiera la Iglesia Católica en España, la Conferencia Episcopal, ni una Asociación religiosa o una Fundación, con reconocimiento expreso en el Acuerdo citado, de personalidad jurídica, la que plantea la cuestión, pero los patrones o fundadores de entidades Cajas de Ahorro, con el matiz de ser promovidos por la Iglesia en definitiva están evidentemente afectados.

Pero además se le reconoce en el Acuerdo sobre Asuntos Jurídicos, la posibilidad de llevar a cabo por si misma actividades de carácter benéfico o asistencial, y esta obra social o benéfica en su caso, es la que singulariza a las Cajas de Ahorro, sin discutir su naturaleza empresarial o no. También es cierto que la Iglesia de común acuerdo con el Estado, puede establecer las bases de adecuada cooperación en actividades de beneficencia o asistencia. ¿Pero se ha hecho esto a través de la LORCA? Evidentemente no.

La realidad es que en atención a lo prescrito en cuanto a representantes, de la más diversa procedencia, en las Cajas de Ahorros patrocinadas por la Iglesia desnaturaliza sensiblemente éstas al trastocar de forma esencial sus Organos Rectores. En su lugar hemos pormenorizado la trascendencia y cambio operado, con una gran disimilitud a lo que intencional y originariamente eran. Se han transformado "ope legis", pero no en consenso, sino por una solución de Estado no convenida con la Iglesia. 
El tema es delicado, casi espinoso, no se tiene noticia de lo acontecido y de la transformación experimentada, ni de la posible o futura reacción de las Autoridades eclesiásticas. Justificamos esta actitud por el proceder cauto y a veces lento de la reacciones y acciones en el mundo eclesiástico en relación con temas temporales y más aún en supuestos como éste de claro contenido económico.

Aspectos importantes como los de legitimación, capacidad procesal, jurisdicción pertinente, formalización del recurso, naturaleza del mismo, son interrogantes decantadas y resueltas en el tiempo, o tal vez sin resolver y en espera de acontecimientos de futuro.

Pero no sólo están interesados, y los son; legítimos los fundadores, hay otros intereses, por deducción interesados, como las Comunidades Autónomas donde radiquen o ejerzan su principal actividad estas Instituciones, que también pueden actuar y en previsible futuro pueden hacerlo.

Lo evidente en este caso concreto es que por Sentencia de nuestro más Alto Tribunal la cuestión ha sido zanjada y no puede volver a plantearse, en los mismos términos. Otra cosa es se haya satisfecho la pretensión y se haya resuelto la cuestión. No hay contradicción por fallo judicial del Tribunal Constitucional, pero como se añade no es cuestión suya la cuestión de la supuesta contradicción, aqui si se produce una "contradictio in terminis": primero se dice que la Ley impugnada no deroga, contradice o suspende cláusula alguna del Convenio con la Santa Sede y a continuación, en el siguiente punto y seguido, se dice que su examen no le corresponde y no procede entrar en el fondo del asunto. Cualquier lector de ésta, generalmente difícil, por su lectura, sentencia, al menos se queda perplejo, pues no sabe a qué atenerse. $Y$ no creemos bueno entrar en un mundo de perplejidades, indecisiones, irresoluciones pues la ambigüedad es germen de confusión y ésta no propicia la pacífica convivencia.

El tema es susceptible de una mayor reflexión, estudio en profundidad, examen de la evolución y cómo se ha llegado al estado de la cuestión de retro y prospectiva, pero por ahora queda significada y reparada una interesante materia, sobre la cual habrán de plantearse no pocas incidencias desde una plataforma, insistimos insegura en búsqueda de la necesaria seguridad.

\section{ALGUNAS PRECISIONES Y APRECIACIONES SOBRE EL PAPEL DEL BANCO DE ESPAÑA EN RELACION CON LAS CAJAS DE AHORRO}

Con la misma ideología reflexiva de siempre, lejos de cualquier dogmática y sin ánimo de proselitismo, ofrecemos unas sugerencias 
sometidas a critica desde este instante, que distan de ser argumentos concluyentes, en tanto por su naturaleza como intención.

El binomio Banco de España/Cajas de Ahorros, es susceptible de articulación en las más diversas facetas $y$ en las múltiples combinaciones posibles, ofrece una riqueza en el trasunto, de la cual mostramos algunas relaciones, por su especial relevancia.

Hay hechos evidentes incuestionables como aspectos institucionales de las Cajas de Ahorros, el primero no sólo por su importancia sino por su vigencia, es el de que aquéllas buscan su identidad en un proceso de reestructuración y acoplamiento financiero (1), provocado por factores como el libre establecimiento y su incentivación a nivel autonómico y la próxima, ya inmediata, incorporación a Europa, con la creación en 1993 de un mercado único han hecho modificar los planteamientos tradicionales.

Es evidente la significación política, aunque sean puros instrumentos técnicos, que por su importancia crediticia, de intermediación en el ahorro y depósito trascienden y son agentes significantes en un mundo político, donde el desarrollo económico, el crecimiento y otros factores tienen un protagonismo evidente, del que no se excluyen las Cajas de Ahorro. A nivel de ciudadano este proceso se inició y tuvo eco desde 1985 con la LORCA (Ley 31/1985, de 2 de agosto, de Regulación de las Normas Básicas de Organos Rectores de las Cajas de Ahorros) en una polémica trascendente al gran público y a todos los medios de comunicación social, por esa posible politización a través de la representatividad en las mismas, sobre todo de las Corporaciones Locales.

Las referencias a los mercados, a su dimensión, a las formas de gestión, a la oferta nueva, a distintas penetraciones en el sector financiero a la nueva extensión y ubicación de la geografía española y europea son retos que están ahi y a los que hasta el momento se ha respondido de diferente forma: o se ha apostado por el crecimiento,

(1) Vide, la prensa especializada periódica o no, en relación con el sector económico financiero, como ejemplo Rating (el nuevo lunes) núm. 13, julio de 1989, año II: "Radiografia y calificación de empresa". Dirigida por Rosa Abad, que en la carta dirigida a los lectores en el núm. de la Revista cit. , afirma es éste el año de la expansión y de las fusiones y denuncia este proceso de búsqueda de identidad. Este número de revista monográfico, dedicado a las cajas de Ahorro, en sus diversas secciones, aporta significativas colaboraciones interesantes pues muestran el estado de opinión más reciente, sobre las Cajas de Ahorro. Vide, Joan Pinto: "La solvencia, la mejor garantía para el cliente" (pág. 11); Jaime Terceiro: "Hay que compaginar ..." (pág. 14); Germán Pérez Ollauri: "El futuro de las Cajas de Ahorros" (pág. 18); Manuel A. Sempere: "Cajas: pistoletazo de salida hacia las fusiones" (pág. 31); Manuel Muela: "Las cajas se adaptan a los cambio" (pág. 135); así como reportajes, en cuestas e informes de dicha publicación. 
los ejemplos son tan recientes y numerosos qué obviamos su referencia, o por la rentabilidad, sedimento y eje de propulsión consciente o inconscientemente siempre presente en las Cajas de Ahorro, o por la especialización en su área de influencia, de lo cual también hay evidentes muestras. Por supuesto la regionalización, las trabas impuesta a nivel autonómico para evitar la dispersión o el traspaso de inversiones y del ahorro captado en su territorio e invertido en otro y cuantos motivos hemos suficientemente examinado en el apartado correspondiente.

La decisión actual, y estamos constatando un hecho palmario, es de ampliación de actividades y entrar en competencia con la banca nacional o extranjera, para decidir en lid con otros intermediarios la hegemonía o en su caso el reparto del poder financiero.

El Banco de España ante esta situación se muestra como árbitro y ejerce sus funciones, a nuestro entender con prudencia y con un respeto hasta ahora por los destinatarios de sus orientaciones, prevenciones y normas. Aconseja y manda, dirige y disciplina, supervisa y corrige, coordina y reprime en ocasiones. Actúa de árbitro único en la contienda y bajo la dirección del Gobierno, último responsable de la política monetaria y del crédito, resuelve en pacificación, "aunque no con la anuencia de los perdedores, si los hay. Pues aunque no se manifiesta, pues son las reglas del juego del sigilo, secreto, confidencialidad tradicionales, hay elementos renuentes, lo cual en un futuro ha de tener su trascendencia.

Es un mandato legal imperativo en los sectores de intermediación financiera, el ejercicio profesional eficaz, la profesionalización, la intervención de aficionados aunque sean influyentes y con recursos importantes, cada día se descarta más, la trasparencia, la cual quiebra el principio tradicional del sigilo, la democratización por vía de representatividad; todos estos ingredientes hacen cuestionarse y resquebrajarse cimientos centenarios de algunas Entidades de Ahorro.

En un momento de crisis, aunque paradógicamente no lo parezca, pero un hecho evidente está en que de las 77 Cajas de Ahorros, Confederadas todas actualmente, más de dos tercios buscan en una dimensión superior, mediante la fusión la solución de sus problemas, luego algo pasa en el sector, antes respetado por sus competidores: la banca, en un reparto tácito del mercado en lineas generales el por menor para las Cajas el por mayor para la banca. Los términos se han alterado y el pacto hoy no se respeta, los bancos se convierten en entidades más domésticas, más próximas al cliente, le ofrecen incentivos incluso superiores, en apariencia o realidad, y las Cajas sobre todo las que podríamos llamar importantes, compiten con la banca privada en las grandes operaciones. Se ha roto esa pacifica convivencia y aparece la 
agresividad con unas formas comunes de actuación y poniendo al servicio de la gestión las más modernas y sofisticadas técnicas, donde la imaginación y la creatividad tienen bastante que decir.

De poco tiempo hasta hoy parece que la solución la iniciaron los bancos con las OPAS, término ajeno, pronto asimilado y matizado de amistoso o agresivo, la siguieron las Cajas, después de un receso ha vuelto a cuestionarse.

La justificación de estas nuevas actitudes de colaboración está en que en un mundo como el actual y en un previsible próximo, es imposible actuar aislado y en pequeña dimensión; los grandes espacios, no sólo comerciales, sino financieros se imponen, y el respaldo se encuentra en los incentivos de las economías de escala, posiblemente alcanzables desde la nueva dimensión y las desgravaciones fiscales obtenidas, pues el Gobierno con un criterio de política financiera incentiva estas uniones. En reflexión sólo una observación: los problemas de insolvencia, de crisis interior, de mala gestión y peores resultados, no los resuelve una panacea, aparentemente universal, como es la de la fusión, el ser más grande no garantiza ser el menor, se ha dicho y con razón.

El Banco de España cáutamente advierte que la contienda licita puede degenerar en lucha, sin reglamento, en reyerta, por eso en general los intermediarios financieros habrán de tener en cuenta la reglas "del juego ahora beligerante. No siempre la unión, la dimensión, el volumen de negocios e inversión superiores garantizan el éxito, incluso diriamos el riesgo es superior, la responsabilidad mayor, la realidad más compleja, la competitividad más agresiva, pues si desaparecen determinados oponentes aparecen otros, más fuertes, en liza. Todo ello produce un desgaste evidente y un deterioro manifiesto, entendemos la intervención del Banco Central, del Banco de Bancos qué es el de España, se debe centrar en evitar estos deterioros en perjuicio al final, del sistema económico, monetario y crediticio.

En el nivel de digresión alcanzado se observa que el discurso que hacemos, parte de un examen de la realidad Cajas de Ahorros y la reacción presente o en potencia de competencias, atribuciones y facultades del Banco de España. Con un afán de no replantear, cuestionar o repetir asuntos o bien tratados o supuestos ya y solucionados al menos a nivel teórico, el riesgo ahora y somos conscientes, se encuentra en la reiteración, tal vez monotonía argumental, desde luego posible repetición, aunque justificada en esta mera articulación, casi simbiótica, pues las Cajas no pueden campar por sus respetos y el respeto que han de tener se llama Banco de España, sea Gobierno o Ministerio/Ministro de Hacienda, pues en definitiva es el brazo ejecutor, el interlocutor válido y próximo, sobre el cual no hacemos 
alusiones como tal entidad, estudio importante pero desvíado de nuestro objetivo, aunque naturalmente se realicen observaciones, en relación con el mismo.

El Banco de España en uso de sus atribuciones vigila la solvencia de las Cajas de Ahorros pues la última "ratio" es sensible: la solvencia en las entidades financieras se convierte en garantía para los depositantes en las mismas, del retorno de sus efectivos depositados.

Ante una situación no declarada pero real, por un riesgo de insolvencia que se acusa en un cierto sector de Cajas de Ahorros, soluciones aparte de la fusión que cuestionamos como remedio aparente más que real, se han anunciado como la aprobación reglamentaria de medidas sobre cuotas participativas, que serían títulos sin derechos políticos y computables como recursos propios de las Cajas de Ahorros, asi como la emisión de deuda subordinada.

Estas cuotas participativas, cuya regulación legal se ha comprometido el Gobierno será una realidad en 1989 (2). Con este titulo valor se pretende dotar a las Cajas de Ahorros de un medio para captar fondos propios y cubrir el coeficiente de solvencia, lo cual es una exigencia importante en el momento actual del Ahorro. Se ha producido además en este momento, en 1988, una circunstancia determinada por el Banco de España, de dotar los fondos para complementos de pensiones del personal de las Cajas de Ahorros, y esta atención no ha podido ser tenida en cuenta por un sector de las mismas. El coeficiente de recursos propios de estas Entidades de Ahorro, lo considera el Banco de España como un baremo e indicador de su estado satisfactorio en su solvencia como Entidad de Crédito.

Esto se ha producido por la incapacidad que tienen las Cajas de Ahorro, como hacen las demás entidades bancarias, de acudir a ampliaciones de capital por lo cual tienen que recurrir a destinar a reservas los excedentes de capital y esto en detrimento de su obra benéfico-social, que en definitiva, como hemos afirmado, les justifica y se debería potenciar.

El sistema de cuotas participativas supone para las Cajas de Ahorro competir en cuanto a rentabilidad con otras Entidades financieras en este aspecto, en un momento en el concierto europeo donde se

(2) Vide, Revista Rating cit. en nota anterior, núm. 13, pág. 6 que bajo el título Accionistas sin voto dice literalmente: "El Ministro de Economía, Carlos Solchaga, en el transcurso de la Asamblea Anual de Cajas de Ahorro Confederadas, celebrada los dias 20 a 22 de junio de 1989, en Madrid, LIX Asamblea General Ordinaria de la CECA, anunció que en el presente año de 1989 culminaría la regulación legal de las cuotas participativas de las Cajas de Ahorros", aclarando después la naturaleza de las mismas como títulos valores que otorgan a sus suscriptores derechos económicos pero no políticos, estos últimos se representan por el derecho al voto. 
discute si no seria conveniente convertir las Cajas de Ahorro en Sociedades Anónimas.

Como se observa el panorama, lejos de una aparente tranquilidad y trasparencia, ni es de pacífico desenvolvimiento y aspectos de opacidad aparecen, cuando se necesita de estos ingrediente de normal desenvolvimiento y claridad de presente y previsible futuro. El papel del Banco de España va a ser decisivo, lo está siendo en este momento sobre la base y hasta ahora de un común consenso en cuanto a su pericia y ponderación en acuerdo de no disensión, aunque molesten sus decisiones y reconocimiento de su autoridad indiscutida en razón de un buen funcionamiento y una sensación de seguridad, necesario caldo de cultivo para una próspera intermediación y un desarrollo de futuro y una sanidad de presente, en la negociación bancaria, aspectos todos ellos trascendentales y en los que el Banco de España arbitra los medios necesarios.

Hemos hablado del posible detrimento de la obra benéfico-social y esto se debe ponderar con arreglo a los resultados actuales, cómo reaccionan las Cajas de Ahorro en su conjunto en términos de participación en 1988, donde se obtuvo un excedente próximo a los 137.000 millones de pesetas y en porcentajes se destinó a reservas un $52,6 \%$, un $17,8 \%$ a previsión del impuesto de sociedades y un $29,5 \%$ a la obra benéfico-social (3). La distribución de excedentes líquidos en obra benéfico-social, ha experimentado una evolución donde el Banco de España interviene de forma fehaciente en la actualidad, desde su regulación por Real Decreto 502/1953, de 9 de marzo, lo mismo que hace el Ministerio de Economía y Hacienda, que tiene especiales competencias al respecto. La competencia y atribuciones del Banco de España se refieren a obligación de información o para realizar proposiciones en determinados supuestos según el Real Decreto 502/1983; para que el Ministerio de Economía y Hacienda aplique otros porcentajes de distribución de excedentes (art. 4.1); el Banco de España propone al Ministerio de Economía y Hacienda la aplicación de porcentajes de

(3) Vide, la cit. Revista Rating, pág. 137 donde se recogen los datos relativos a la LIX Asamblea General de las cajas de Ahorro Confederadas, donde se cifra, a finales del 1988 el saldo de recursos ajenos en 14'9 billones con más de 45 millones de depositantes, con una ganancia de cuota de mercado de 2'51 puntos porcentuales, en cuanto a los titulares de cuentas a fin de 1988 eran $45^{\prime} 3$ millones, con un saldo medio de 330.000 pesetas, que supone una tasa de crecimiento, respecto del año anterior, en orden al 18\%. En cuanto a la expansión el número de Oficinas abiertas superó las 500 y llega a número total en España de 12.310, y con presencia en el extranjero, pues desde febrero de 1988, funciona en Londres una sucursal operativa de la CECA. Las ponencias de la Asamblea, celebrada los días 20, 21 y 22 de junio de 1989, fueron: I La Economía Española en el momento actual; II. Las Cajas de Ahorros Confederadas en el sistema financiero español y III? Las Cajas de Ahorro españolas ante 1992. 
dotación de reservas superiores a las mínimas para las Cajas de Ahorros (art. 4. 2); Obligación del Banco de España de remitir la propuesta de distribución de excedentes, aprobada en cada ejercicio. La propuesta de las Cajas de Ahorros la recibe aquél por imperativo de la Orden de 19 de junio de 1979 (art. 5) (4). El Real Decreto mencionado de 1983, intensifica el destino de excedentes, para acrecentar los recursos propios y reforzar el coeficiente de garantía, el carácter eminentemente social y benéfico de las Cajas de Ahorro queda garantizado con esta normativa.

Los criterios establecidos para la obra benéfico social son: que esté orientada hacia la sanidad pública, investigación, enseñanza, cultura y servicios de asistencia social y que los beneficios derivados de tales actividades se extiendan especialmente al ámbito regional de la actuación de la Cajas de Ahorros respectiva. Se crea al respecto una Comisión de Obras Sociales, por Decreto 2290/1977 con la misión específica de seleccionar y administrar las obras de esta naturaleza, que hayan de nutrirse de los excedentes libres de las Cajas de Ahorro, de esta forma se deslindan las tareas asistenciales, de aquellas otras que son típicas de administración financiera.

Las normas relativas a la obra benéfico-social de las Cajas de Ahorro se disciplina por Orden del Ministerio de Economía de 19 de junio de 1979 y se establecen distintas posibilidades, en cuanto a la realización de la misma: obra benéfico-social propia, en colaboración y obras ajenas, según se realice la gestión y administración por una o varias fundaciones y la misma se realice a través de Patronatos, creados por las Cajas (5).

(4) Vide, en la Revista de Administración Pública del País Vasco, R. A. P. V. , núm 12, de 1985, págs. 81 y sgts. , el artículo de Marta Franch Saguer: "Competencias de las Comunidades Autónomas sobre la obra benéfico-social de las Cajas de Ahorro" (especial referencia a la Comunidad Catalana), en especial el ap. 3. Distribución de excedentes líquidos. Obra benéfico-social, págs. 88-92, donde la autora examina el punto 1. Normativa estatal y estudia el régimen jurídico, en su evolución, hasta el vigente en la actualidad, examinando en el punto 2. Control que ejerce la Administración Central, donde cita con apoyo normativo, las competencias del Ministerio de Economía y del Banco de España, vide, págs. 91 y 92 del articulo de referencia antes cit. Vide, Real Decreto 502/1983, de 9 de marzo (BOE del 15 de marzo).

(5) Vide, el art. 2 de la Orden de 19 de junio de 1979, donde se ofrece una definición, como "en la que la inversión, sostenimiento anual y administración sean a cargo de la Caja exclusivamente". El art. 3 define la colaboración como "las realizadas con otras Instituciones o personas físicas o jurídicas". El art. 7 establece la posibilidad excepcional de la atención a obras ajenas. El art. 7 establece la posibilidad excepcional de la atención a obras ajenas. El art. 10 se contempla la gestión y administración a través de Fundaciones o Patronatos. También vide, Derecho 1838/1975, de 3 de julio; Real Decreto 2290/1977, de 27 de agosto (arts. 22 y 23) y la Circular del Banco de España núm. $1 / 1981$. 
Es singular una comparación entre la dedicación a la obra benéfico-social en el reciente ejercicio económico de 1988 , cerca del $30 \%$ de excedente liquido, como hemos visto y la regulación por la que se establece la aplicación que deben dar las Cajas de Ahorro a dicho excedente, con dos condiciones: el destino a la constitución de reservas obligatorias debe ser un porcentaje mínimo en relación con el coeficiente de garantía que cada Caja mantenga y que la parte no aplicada a reservas se dedicará necesariamente a obras benéfico-sociales (6).

Con estas y otras posibles alusiones, se demuestra que las continuas referencias normativas a la obra benéfico-social y la posible aplicación de otros porcentajes en la distribución de excedentes, con lo cual el carácter eminentemente benéfico social se asegura.

La intervención del Banco de España, que hemos analizado, se completa con su capacidad de propuesta para que el Ministerio de Economía autorice la acumulación del $50 \%$ de los excedentes de varios ejercicios en el caso de que los obtenidos en cada uno no les permita a las Cajas de Ahorro la completa realización de los fines previstos (7).

Por su trascendencia hemos abordado estas precisiones al final y alguna de las apreciaciones normativas y comentario, pues coincidimos con algún sector doctrinal (8), en relación con la polémica últimamente planteada por cuestionarse, como hemos visto con la Sentencia del Tribunal Constitucional 49/1988, de 22 de marzo, en torno a la naturaleza de las Cajas de Ahorro como entes fundacionales, a las que se niega tal carácter al amparo del art. 34 de la Constitución Española, y se habla del oscurecimiento del "aspecto benéfico-social", cuestión en la que disentimos, pues tal vez sea en este aspecto tan relevante, en donde habria que insistir para llegar a un convenio

(6) Vide, Real Decreto 502/1983, de 9 de marzo (BOE del 15), cuyo arts. $1^{\circ}$ y $2^{\circ}$ establecen lo dicho en el texto. Esto contrasta con el destino, en el ejercicio de 1988, de las Cajas de Ahorro, con el $52^{\prime} 65 \%$ destinado a reservas y el $29^{\prime} 51 \%$ a la Obra benéfico-social, según los datos de la LIX Asamblea General de las Cajas de Ahorro Confederadas antes citada.

(7) Vide, art. 11 de la Orden de 19 de junio de 1979 (BOE del 29), que contempla este supuesto, también Dessantes Guanter, J.M. : "La titularidad de los bienes afectos a la obra benéfico-social de las Cajas de Ahorros". Cuadernos de trabajo de la Convención de Asesores Jurídicos de Is Confederación Española de Cajas de Ahorro, en el núm. 9, Madrid 1983.

(8) Vide, Antón Pérez, José Antonio: "El Tribunal Constitucional y las normas reguladoras de las Cajas de Ahorros", en Papeles de Economia Española, núm. 39, Madrid 1988, la pág. 178 primera y segunda columnas alude al tema del "oscurecimiento" y al carácter fundacional de las Cajas de Ahorro y manifiesta su opinión: "... la obra benéfico-social adquiere una relevancia que no ha sido debidamente captada por el Tribunal Constitucional a nuestro entender" según columna, al final de la pág. 178. 
generalizado sobre el carácter y naturaleza de estas Entidades, donde el carácter fundacional y su sentido benéfico-social son notas caracteristicas y definidoras.

Un análisis de la naturaleza de las Cajas de Ahorro en la actualidad nos obliga a un tipo de precisiones sobre una realidad, a veces compleja y por demás paradójica: de un lado crecen, aumentan la cuota del mercado con respecto al sector bancario, pero existe una evidente caída de los beneficios, que descienden en un $30 \%$ en relación a 1987, como consecuencia de las mayores dotaciones a fondos de pensiones de su personal, con un proceso evidente de expansión y fusiones (9). El reto consiste en la recuperación y en ponderar la fusiones y colaboraciones, pues se ha llegado a afirmar la fusión no es la mejor solución pues comporta costes elevados y tiene una evidente complejidad, sin embargo se habla de que más de la mitad de las Cajas de Ahorro han iniciado un proceso de fusión a veces bajo fórmulas de colaboración. Se siente pues una necesidad de trasformación, puesta de manifiesto en estos días por los expertos de la Comunidad Económica Europea, que afirman es imperativo el adaptar las Cajas de Ahorro españolas cara a 1993, con la creación de un mercado único europeo.

Desde luego partir de un supuesto evidente: la existencia de 77 Instituciones es manifiestamente excesivo en cuanto a número, pero además con muy distinto carácter, importancia, volumen de negocios, rentabilidad y especialización. Se enfatiza sobre las Cajas de menor tamaño, que en principio deberian fusionarse pues el tamaño no significa aquí correlato de rentabilidad, la suma de entidades no suficientemente saneadas, cosa usual en relación con la dimensión pequeña, en ocasiones injustificada, no supone evidentemente rentabilidad.

Determinar cuantas Cajas de Ahorro deben pervivir no es fácil, pero pueden establecerse alguno parámetro: una adecuación con las existentes en las Comunidades Europeas, en la actualidad existen demasiadas, hay un inconveniente en cuanto a la distribución por Autonomías y deberá tratarse en este ámbito el tema y la fusión o colaboración por Comunidades Autónomas. No es la mejor solución

(9) La reiterada cita del número monográfico de la Revista Rating, núm, 13, julio de 1988, año II, nos obliga a hacer alusión al estudio que se hace en la misma (págs. 42 y sgts.), de la 77 Cajas de Ahorro existentes en España, se examinan con una rigurosa metodologia, por la descripción de la variables utilizada (pág. 44), las 50 primeras (págs. 46 a 118) y las 27 restantes (págs. 119 a 132) como resto del sector, verdadero contenido de este número de Revista, pues al estudio de todas las Cajas de Ahorro españolas se dedican la mayor parte de las páginas. Vide, el examen en resumen de la página inicial 42, bajo el titulo: "Las Cajas crecen y aumentan cuota de mercado". 
en principio, pero inciden de forma notable las competencias amplias que sobre la materia tienen las mismas, las vias de colaboración, fusión o posibles fórmulas de unión hay que ponderarlas, como acción no indiscriminada (10).

Retomando el tema de la intervención del Banco de España en incidencia sobre las Cajas de Ahorro se deben realizar algunas observaciones ya aludidas pero que demandan concreción. En primer lugar la propia naturaleza de la Institución como: "Entidad de Derecho Público, con personalidad jurídica propia y plena capacidad pública y privada, que para el cumplimiento de los fines señalados en el art. tercero, actuará con autonomía respecto a la Administración del Estado, dentro de los límites establecidos en esta Ley", descripción legal de la Ley 30/1980, de 21 de junio, de Organos Rectores del Banco de España, en su artículo primero. La definición se comenta por sí sola, y muestra fehacientemente el protagonismo de la Institución, que actúa como Banco de Bancos, según prescripción legal (art. 3) y a estos efectos las Cajas son entidades bancarias, la labor directiva, de coordinación, de registro, de supervisión, de disciplina e intervención en general se han intentado manifestar, son impactos determinantes $y$ muy caracteristicos.

Habría que evaluar el ordenamiento jurídico bancario en relación con el propio Banco de España y el apoderamiento competencial en su favor, a través de una serie de normas del más diverso rango jerárquico y formal, pero lo interesante no es el análisis ni examen calificador de aspectos adjetivos, sino substancialmente su configuración en un sistema, que por complejidad, no completo por las observaciones antes ya realizadas, no resuelve el sector económico financiero, crediticio, pues hay que tener tranquilidad, no se puede actuar "con premura", aunque objetamos se podría haber hecho, lo cual contribuir de forma evidente a clarificar y hacer más operativo el desarrollo de actividades necesitadas de claridad y trasparencia, en evitación de

(10) Vide, Rating el núm. 13, julio de 1989 cit. Rosa del Río, Directora en su carta editorial: "Las Cajas buscan su identidad" afirma: "De las 77 Cajas existentes en nuestro pais, casi 50 han llegado a acuerdos de colaboración o fusión o están en negociaciones para ello". El tema es común denominador y todas las colaboraciones aluden al tema. Vide, los arts. de Josep-Joan Pintó: "La solvencia, la mejor garantía para el cliente" págs. 11 y sgts. ; Jaime Terceiro Lamba: "Hay que compaginar las responsabilidades social y económica" págs. 14 y sgts.. ; Germán Pérez Ollauri: "El futuro de las Cajas de Ahorro" págs. 18 y sgts. ; el Informe de la Revista, "Cajas, pistoletazo de salida hacia las fusiones" págs. 31 y sgts. : la entrevista con Jaime Terceiro Lomba, págs. 38 y sgts. donde afirma: "Los procesos de fusión hay que empezarlos por las Cajas de menor tamaño". Las declaraciones del Gobernador del Banco de España, en la LIX Asamblea de la CECA cit. donde afirma: "La fusiones de Cajas de Ahorro, sobre todo, no deben verse influidas por factores espúreos ...", la pág. 137 recoge esta referencia. 
opacidades y situaciones de inseguridad por vacio, inconcreción o falta en definitiva de un apoyo legal suficiente, reconociéndose a primera vista las atribuciones y las reacciones ante incumplimiento.

Una nota característica y no siempre bien evaluada es la discreción, ésta es el motor de la aparente tranquilidad, de la falta de conflictividad sobre estos temas, no se suelen dar conflictos pues evitar, al menos en apariencia, existen disensiones, pareceres enfrentados, tensiones o desacuerdos, es fundamental y sobre este sigilo casi secreto en ocasiones, descansa todo el sistema y en aras a esta situación mantenida a costa de cualquier sacrificio, se padece, se soportan cargas y no hay formalmente discusión. Esto se ha mantenido durante decenas de años hasta que con motivo de la Organización autonómica, de la importante intervención de las Comunidades Autónomas en el sector y la reciente crisis económica, ahora aparentemente superada, se pusieron de manifiesto disparidades importantes, sobre todo acerca del reparto competencial en torno a las Cajas de Ahorro entre el Estado y las Comunidades Autónomas y pruebas fehacientes y ejemplares son los recursos de inconstitucionalidad acumulados y resueltos por Sentencias 48 y 49 de 1988, de 22 de marzo, ya suficientemente examinadas, por la doctrina, pero las Entidades de Ahorro interesadas siguen, aparentemente, por ese factor de referencia de la confianza, en silencio y sólo hay en muy rara ocasión voces discrepantes, por otra parte poco significativas para la sociedad y desde luego no asequibles ni escuchadas por el gran público.

Atinadamente se ha aludido doctrinalmente a la crisis como un fenómeno periódico en la actividad bancaria española y como consecuente la readaptación, reorganización, retoques o reformas parciales como consecuencia de aquélla. Pero se produce una falta de vitalidad actualización del ordenamiento del sector crediticio y bancario, con una falta de teorización la cual es una enfermedad endémica en nuestro país, a pesar de intentos recientes (11). Ha habido evidentemente reacciones, nuevas ordenaciones pero que han actuado siempre parcialmente y han pacificado la cuestión momentáneamente, quizá las

(11) Vide, Fernández Rodriguez, Tomás Ramón: "El ordenamiento crediticio bancario español: reflexiones después de la crisis", art. en el Comentario por este tratadista dirigido, a la Ley de Disciplina, op. colectiva (págs. 9 y sgts.), “Comentarios a la Ley de Disciplina e Intervención de las Entidades de Crédito" en donde se estudia con agudeza ejemplar la asociación del fenómeno crisis y el ciclo crisis-ordenación bancaria (pág. 10). En relación con el estado del nivel de teorización sobre el derecho Público Bancario, vide algún muestra significativa como son los "Estudios de Derecho Público Bancario" dirigidos por Sebastián Martín Retortillo, Ed. Ceura, Madrid 1987, aporte de cierta importancia, pero iniciatico y puntual, de una serie de colaboradores, con desigual participación. 
razones son como el sector funcionaba regulado parcial o provisionalmente incluso con ordenaciones vetustas, al producirse fenómenos nuevos imprevisibles no existían mecanismos suficientes e idóneos, en ese momento se reflexiona y se toman medidas, generalmente ya obsoletas pues es difícil o imposible predecir el futuro. Un uso indiscriminado de poder y de normación hipertrofia la cuestión y el régimen jurídico deviene en motorizado o excesivo, pero una pacífica complacencia y un ausencia de instrumentos legales hábiles, pues los ya antiguos y los vacíos normativos no se cubren, provoca en el sentido contrario atrofia por falta de uso, un poco esto es lo que nos ha ocurrido y así se evidencia por contraste la utilización de vías de dudosa legalidad formal, como son la producción normativa del Banco de España, fundamentalmente por el cauce de las Circulares, examinado suficientemente la necesidad se impone y se reacciona, para que a su vez proteste sectores cualificados sobre el orden y la forma y las atribuciones y competencias asignadas, parece no habilitan suficientemente a un normativa menor a ocupar el espacio lógicamente atribuido a órgano distintos con un fuste superior. No obstante todo ello evidencia la realidad de un planteamiento nuevo e imaginativo, no se puede somete a rigurosas dogmáticas, incluso frecuentemente tradicionales, como se ha hecho, situaciones, supuestos y casos de difícil comprensión desde una legalidad a ultranza, pero en definitiva derecho es lo que se vive y no lo que se escribe, $y$ el derecho dictado por el Banco de España hasta ahora ha sido copiado y obedecido por las Cajas de Ahorro.

Otra cosa es el futuro, y en esto no puede nada de dejar de insistir, la mítica fecha de 1992, ya muy próxima, va a cambiar las reglas del juego, las directivas de la Comunidad Europea; por imperativo constitucional al firmar España el Pacto de Adhesión al Mercado Común, se convierten en derecho interno, la adaptabilidad se impone y se ha dicho en los foros públicos por autoridades económicas de responsabilidad en el concierto de Europa: o se cambia o desempeñamos un papel subalterno, doméstico, desfasado y perjudicial. Replantearse cuestiones como la del número de Entidades, 77 parecen demasiadas; de sucursales, más de doce mil, son excesivas; titulares de cuentas de depósitos, 45'3 millones de depositantes coincidente casi y superado en ocasiones la población española (12). Aquí pasa algo,

(12) Vide, el informe a finales de 1988, presentado en la LIX Asamblea General de las Cajas de Ahorro Confederadas (CECA), que resaltaban con énfasis: "A finales de 1988 , el saldo de recursos ajenos ascendia a 14'9 billones de pesetas y habia más de 45 millones de depositantes". Referencia no nuestra sino recogida en Rating, Revista cit. núm. 13, julio 1989, pág. 137, asi como los datos del texto, ofrecidos los días 20, 21 y 22 de junio en la Asamblea, celebrada en Madrid, con unas ponencias interesantes a este respecto, sobre todo la III. "Las Cajas de Ahorros ante 1992". 
pues las cifras son de una expansión, prosperidad y alegria que pueden producir una crisis de crecimiento, pues si por atrofia se da por hipertrofia también. Una prosperidad exultante esconde a veces disfunciones y el exceso o el defecto son perjudiciales, se debe reflexionar y reaccionar desde cauces idóneos, no meramente formales.

Tal vez la envergadura del problema, su amplitud y natural importancia no es susceptible de generalizaciones ni de soluciones simplistas. El tema es complejo y se ha reconocido, como hemos señalado, a nivel legal y de Ordenación, en el Preámbulo de la Ley de Disciplina e Intervención de las Entidades de Crédito, huérfanas de una Ley general, que en esta ocasión tampoco se promulga por cautela, se aprovecha la ocasión para resolver sólo ciertos problemas, los más acuciantes aparentemente, pero la mesura, la prudencia, el ir lento para actuar deprisa, se vuelven a imponer y esta actitud adecuada en el siglo pasado e incluso en éste, no es válida en el XXI, que aunque no cronológicamente empieza ya con la década de los 90 , con anticipación.

Esa incapacidad para dar un trato único, pues todavía permanecen ciertas limitaciones para dar plena capacidad a todas las Entidades de Crédito especializadas, para utilizar determinadas modalidades de captación de fondos de la clientela. Si bien se ha logrado la regulación general de las operaciones de arrendamiento financiero, se han abordado temas centrales y capitales, un ejemplo es la regulación disciplinaria, antes fragmentaria, dispersa, inconexa y defectuosa, pero no se atiende en su totalidad la política impulsada por la Comunidad Económica Europea de establecer no sólo un marco común de la supervisión y disciplina, que sí se ha hecho, sino de la ordenación del crédito y la banca y de los intermediarios financieros, asignatura aún pendiente en importantes aspectos con los medios técnicos ahora disponibles, con la profesionalización y competencia evidentes del Banco de España, con la anuencia de los destinatarios especialmente obligados $y$ dispuestos a soportar la carga de la supremacia especial ejercida y con una serie de factores, ahora no citados, favorables es posible abordar y no con premura sino con eficacia y celeridad lo ahora soslayado. Es evidente la solución no es simple como no lo es el problema, pero en congrua consecuencia se deben arbitrar complejas medidas, en una ordenación no necesariamente complicada pues las soluciones son claras a pesar de hipótesis y planteamientos artificiosos por su naturaleza íntima.

Hemos tratado secuencialmente, en intento de precisar el papel del Banco de España en relación con las Cajas de Ahorro, pero no con una asepsia deseable en todo cuestionamiento cientifico, la razón se encuentra en la falta de apoyo por aportes y soportes doctrinales 
escasos, en el distanciamiento entre regulación normativa y peculiaridad de la misma, en la articulación del mandato de las autoridades del sector y la receptividad con la cual es recibido, en el cumplimiento y/o incumplimiento de la normativa en general, de las apariencias frecuentemente con sombras respecto de la realidad, no proyectándose en ocasiones con nitidez $y$ en oferta una imagen distinta, necesitada de retoques para obtener un retrato auténtico. A éstas se podrían añadir en argumentación otra serie de razones a nuestro entender también determinantes, pero es suficiente las expuestas por no dramatizar el cuestionario en atención sobre todo a nuestra optimista impresión al respecto, si se toman las medidas necesarias para paliar previsibles desajustes y disfunciones, pues la situación es propicia, coyunturalmente idónea y se deben evitar actitudes trasnochadas, muy poco operativas, aceptando el reto, que no es tan peligroso ni tan exigente como aparece, pero necesitado de congrua respuesta, la cual se puede ofrecer con los medios disponibles actualmente y en una situación como la vivida en nuestros dias.

Existen temas puntuales en los que se nota la influencia y presencia del Banco de España en relación con las cajas de Ahorros (13) en aspectos como el de vigía, patrocinador y garante de obligaciones contraídas o medidas relativas a la política crediticia, al depósito, a operaciones, servicios o productos financieros.

Hemos denunciado al principio el énfasis que últimamente ha situado el Banco de España, para reforzar la solvencia y garantías genéricas del sistema financiero, materializándose a lo largo del pasado año de 1988 con una decisión, calificada por muchos de radical (14), en materia de dotación a fondos de pensiones para empleados y fon-

(13) Incluso la prensa no especializada, los periódicos diarios en España, publican o bien en noticias nacionales, económicas o como se quiera titular según el periódico, informaciones frecuentes sobre la actitud del Banco de España con relación a la tutela ejercida sobre Cajas de Ahorro. Un ejemplo, ABC en su diario de economia, generalmente en páginas centrales, raro es el día que no hace alguna referencia a Cajas de Ahorros, Bancos y Banco de España. Vide, para confirmar esto, el sábado 21. 10. 89 $A B C$, el trabajo: "Bancos y Cajas de Ahorros no tendrán prórroga para dotar sus fondos de pensiones".

(14) Vide, la cit. Revista rating, núm. 13 (julio 1989), que en traducción equivale a grado, clase, rango o expresión similar, en la pág. 136, publica bajo el título de la sección "marco jurídico" una colaboración anónima, en donde se examina la situación actual y la estudiar los fondos de pensiones califica de decisión radical la actitud del Banco de España en relación con los mismos, igualmente el artículo de C. Baládo/J. L. González Besada, en ABC del sábado 21 de octubre de 1989, pág. 49, "Diario de Economia" bajo el título "Bancos y Cajas de Ahorros no tendrán prórroga para dotar sus fondos de pensiones", cit. nota anterior, cuyo título es lo suficientemente expresivo en lo relativo al tema. 
dos de insolvencias, estableciéndose una fecha: 31.12.1988 para cumplir con los compromisos establecidos, no todas las Cajas de Ahorro han podido cumplir con esta obligación, por tener otras coincidentes, como las necesidades derivadas del coeficiente de garantía. Es evidente la creciente intervención normativa, del que son un buen ejemplo, en el plano legislativo dos importantes Leyes: Ley 24/1988, de 28 de julio, de Mercado de Valores y la Ley 26/1988, de 2 de julio, de Disciplina e Intervención de las Entidades de Crédito, que han reforzado la autoridad del Banco de España.

La vigilancia atenta de la autoridad monetaria, léase en este caso Banco de España, en el proceso de dotaciones a los fondos de pensiones destinados a su personal por parte de las entidades financieras Cajas de Ahorros han tenido en general buenos resultados desde el punto de vista del cumplimiento y en general con naturales excepciones (15). La exigencia establecida por el Banco de España de esta dotación completa para fondos de pensiones de los empleados en activo de las Cajas de Ahorros se debía a los buenos resultados obtenidos por las mismas en el último ejercicio completo, dicha decisión como se ha insinuado afecta de una manera negativa principalmente a las Cajas de Ahorro que vieron sensiblemente mermados su beneficios, en los supuestos de aquéllas con menor cantidad de recursos propios. La autoridad monetaria, Banco de España, no proclive a conceder prórrogas para el cumplimiento de las obligaciones citadas y excepcionalmente parece puede contemplar dicho supuesto referido a Cajas de Ahorros muy pequeñas y a las que ha recomendado fusionarse.

Uh último aspecto sobre el que se debe hacer insistencia, aparte de los ya manidos conceptos e ideas sobre solvencia, recursos, expansión, fusión, etc. tan de moda y boga, a los que habría de someterse a critica y análisis, este panorama es el de la trasparencia, parece que la decisión del Ministerio de Economía y Hacienda actualmente (noviembre de 1989), es la de exigir una mayor trasparencia a las entidades financieras en operaciones con clientes, mediante una Orden Ministerial, remitida para informe al Consejo de Estado, y en la cual se extiende a las Entidades de crédito no de depósito, Compañias de seguros "leasing" o arrendamiento financiero, las mismas obli-

(15) En este caso, según nuestras noticias, a la fecha, en el último trimestre del año 1989, no habian cumplido con la obligación de dotar al fondo de pensiones de sus empleados, la Caja de Ahorros Vizcaina, cuyos problemas podrian resolverse mediante fusión con la caja de Bilbao; también la Caja Provincial de Granada y algunas Cajas de Ahorros muy pequeñas, a las que el Banco emisor ha recomendado fusionarse. Vide, el núm. 13 de rating, rev. cit. , donde se dan los resultados de las " 50 primeras cajas" y las " 27 restantes" en el informe publicado, págs. 42 y sgts. 
gaciones de información que las de la banca o Cajas de Áhorros (16). Se pretende agrupar una normativa dispersa en la materia, con disposiciones de rango formal distinto: de Leyes a Circulares del Banco de España.

Este proyecto clarificador, con una intención de establecer una normativa vigente derogatoria de la anterior, homogeneizará la regulación de la publicidad de todas las Entidades de Créditos, adaptándola a la Ley General de Publicidad, afectando a operaciones, servicios o productos financieros en los que se haga referencia al coste o rendimiento para el público y será el Banco de España el que deba previamente autorizar dicha publicidad, a la que se le va a exigir: concreción, claridad y respeto a la competencia pudiéndose requerir por aquél el cese de la misma o la rectificación. Naturalmente en esta inmediata regulación de la publicidad, aún hoy sin dictarse pero antes de 1989, seguramente vigente, hay matices obvios: la publicidad institucional, la de imagen, de operaciones de servicios financieros donde no haya referencia al coste o rentabilidad para el público, el Banco de España no exigirá, como en otros casos, la autorización previa.

Tampoco se obliga a las Entidades de Crédito no de depósito a publicar sus tipos de interés y prohíbe referencias a las operaciones a tipos de interés practicados por la propia entidad o por otras de su grupo (17).

Las tarifas de comisiones y gastos deben ser públicas y cada entidad financiera tendrá que especificar su contenido material y el ámbito de su aplicación será el de las operaciones que realice la entidad. Con una presentación clara, concreta y de fácil comprensión,

(16) Vide, artículo en ABC de Carlos Balado, publicado el día 13. 11. 89. pág. 56, la edición es la de Madrid y en el resumen inicial del texto, se dice literalmente "Economia ha enviado una Orden Ministerial al Consejo de Estado por la que se exigen mayores requisitos de trasparencia a las entidades financieras en sus relaciones con los clientes. La nueva norma extiende a las entidades de crédito no de depósito, compañias de seguros, leasing, o arrendamiento financiero, las mismas obligaciones de información que la de los Bancos y Cajas de Ahorro. Esta norma agrupa la legislación dispersa de esta materia en distintas leyes y circulares", después, y a tres columnas, se desarrolla el contenido de la Orden Ministerial, remitida al Consejo de Estado para su dictamen, donde se hace un examen de la intención, objetivos, significado y ámbito de la misma.

(17) Vide, Diario de Economía núm. 858, publicado el 13. 11. 89. en el periódico $A B C$ en Madrid, pág. 55, el articulo de Carlos Balado: "Economía exigirá mayor transparencia a las entidades financieras en operaciones con clientes" (el Consejo de Estado estudia la Orden Ministerial que lo regulará), el paréntesis nos corresponde, pues aparece como segundo título aclaratorio en el periódico cit. Examen, de un periodista especializado en temas económico-financieros que da una suficiente y completa noticia al respecto. 
además los tipos de interés deben estar disponibles para su consulta por el público en todas las oficinas de la Entidad de que se trate, se deben presentar al Banco de España, que tiene 15 días para formular objeciones.

La base de esta nueva ordenación está en el agrupamiento de una normación dispersa y de muy diversos rango, heterogénea, además de la Ley General de Publicidad, la de Disciplina e Intervención de las Entidades de Crédito, asi como la regulación por Orden Ministerial de liberación de tipos, la que afecta a la información que las entidades de crédito deben incluir en sus contratos con clientes, así como las Circulares del Banco de España sobre tipos de interés y acerca del funcionamiento del servicio de reclamaciones (18).

Como se ha podido comprobar un estudio normativo, regulador del binomio relacional Banco de España-Cajas de Ahorros, tiene tal dinámica, profusión y vida, que cualquier intento sistematizador queda obsoleto al poco tiempo, se desarticula lo articulado, se desencaja lo encajado $y$ en fin se hace una tarea útil en momento determinado, para convertirse en inútil, muy poco después. La verdad sin embargo se impone: la necesidad de un marco jurídico, el establecimiento de unas reglas de juego claras y precisas, índices, parámetros y criterios de actuación, para adaptarse con facilidad, claridad y seguridad, derivadas que debia ofrecer el ordenamiento, que en versiones tradicionales es incapaz de ofertar, quizá por empecinamiento de fórmulas ya superadas o criterios superables, que con normas se pueden resolver los asuntos, cuando se debe ir más allá, interrogándonos sobre la causas ultimas, de situaciones producidas.

$Y$ ¿qué observaciones en reflexión, se pueden hacer relativas al régimen jurídico ordenador del crédito y la banca?, un planteamiento, como lo es el competencial, supone problemas que derivan frecuentemente en conflicto. También es presupuesto de complejas situaciones, produciéndose antagonismos, ambigüedades e inconvenientes. Consecuencia lógica actual es intentar resolver las cuestiones por vía normativa es decir regulaciones cada vez más pormenorizadas, con ánimo resolutorio, pero como resultado una motorización de disposiciones incrementa la carga conflictual del tema, por discusión entre

(18) Vide, el artículo periodístico cit. , pág. 55, en nota anterior, donde Carlos Balado, su autor, examina la pretensión de esta inmediata Orden, para él publicada antes de fin de noviembre de 1989, de evitar la dispersión normativa, su base en las citadas Leyes y Circulares del texto donde se deben resaltar, aspectos como los de información sobre tarifas y cargos a las mismas, obligadas, derogación normativa, ámbito de aplicación y efectos. Los requisitos obligatorios de la trasparencia, son más exigentes ahora y en el proyecto de Orden Ministerial anunciada, en la actualidad sometida a dictamen del Consejo de Estado. 
los responsables normativos con los destinatarios, o entre las distintas fuentes de producción.

La situación resulta angustiosa, lo cual ha sido denunciado (19) por algún sector de la doctrina. Esta realidad recibida como legado en la actualidad, no es fruto del azar, se produce por razones claras y está en constante incidencia en situaciones cotidianas, pues no hay nada más común que el tráfico financiero, cuando además el agente en la intermediación, son instituciones como las Cajas de Ahorro.

No ha sido la intención de este trabajo el estudio de la génesis, evolución o biografía de las Instituciones de crédito y ahorro. Se reconoce su importancia, pero con un interés más modesto se intenta colaborar en tareas de clarificación, sobre temas recurrentes e importantes, para ofrecer si no soluciones al menos vías, tendencias, posibles recomendaciones en relación con temas como son los de funcionamiento, actividad, administración y gestión, aspectos trascendentales pues una bien ideada organización, subjetiva y orgánicamente diseñada con perfección, puede tenga disfunciones importantes en la práctica, con lo cual no se alcanzan los objetivos previstos, se producen abismos entre la intención, la creación, los aspectos formales y los materiales, de ejecución y funcionamiento.

Hemos partido de un supuesto evidente, la naturaleza de las Cajas de Ahorro, pero sin entrar en discusión doctrinal sobre el ser de las mismas (20), pues se intenta pasar al mundo de la actividad, donde se plantean numerosas cuestiones, derivadas de una inicial complejidad, como es la temática competencial atribuida al Banco de España.

Se ha comprobado existe una exigencia inicial de explicación, de labor hermenéutica, de justificación de las más variadas intervenciones, que se producen en el tiempo y su estudio cronológico, en ocasiones, ha aclarado la situación actual, pero tampoco se ha analizado cómo se ha producido el fenómeno competencial en este dominio.

(19) González Moreno, José Manuel: “Naturaleza y régimen juridico de las Cajas de Ahorro". Madrid 1983. Prólogo de Luis Morell Ocaña, tesis doctoral publicada por la Caja de Ahorros y Monte de Piedad de Madrid, 623 págs. En el Prólogo de Morell Ocaña, Director de esta tesis, se inician sus palabras preliminares con esta afirmación, califica de "particularmente angustiosa" la cuestión (vide, pág. VII) y se refiere al tema objeto de la monografia, es decir la caracterización, que es el inicio de la problemática, complicada "a posteriori" al estar inmersa la cuestión en el farragoso mundo competencial.

(20) Vide, op. cit. nota anterior, cuya intención es determinar la naturaleza jurídica de las Cajas de Ahorros, para llegar a concebirlas como una "fundación empresa", con un carácter unitario y común (vide la conclusión XII, pág. 589), examinándose, a lo largo de la monografia, una inestimable serie de cuestiones Cfr. en especial el epigrafe “Conclusiones", págs. 581 a 614, XLV conclusiones. 
Existe un momento crítico en España, el año 1978, en que se promulga nuestra Constitución y es a partir de entonces cuando se trasciende, hasta el final de la década de los 80 , para encarar hoy en 1989, la situación de las Cajas de Ahorro en su dependencia del Banco de España, en un universo normativo, del más diverso rango, con una proliferación evidente de normas y ante temas como son los competenciales, tan fecundos se debe atribuir a cada uno de los sujetos intervinientes, por sí, por encomienda, directa o indirectamente implicados, cuál es su tarea, cómo la desarrollan, en qué temas se convierte en problema, en definitiva ofrecer un panorama lo más accesible en cuanto a entendimiento, pues el pensamiento constitucional ha sido, es y será presumiblemente objeto de interpretación, comentario y discusión al respecto.

Operativamente pues hemos partido de un concepto juridico: la competencia, sin entrar en disquisiciones sobre facultades, atribuciones, potestades, etc., utilizando este concepto como titularidad de una función pública, detentada por un ente público, sobre una materia determinada. El sujeto, es el titular de la competencia, puede ser un ente o un órgano de este ente público, el objeto es la institución jurídica Cajas de Ahorro, materia sobre la cual recaen unas concretas facultades, que determinan la actuación de dichas instituciones, en un sector concreto el de la intermediación financiera, y el contenido, representado por una serie de facultades, potestades o funciones, en que se concreta la actividad del titular de la competencia, ejercida sobre el sujeto, en una determinada materia. Esta forma tradicional de proceder, al menos no nos sugiere discusión, pues, generalmente es un convenio aceptado.

El sistema de distribución de competencias articulado constitucionalmente, por el medio, conocido habitualmente con la denominación "de lista", establece un reparto competencial entre el Estado y las Comunidades Autónomas que es heterogéneo en un principio al existir dos tipos de Autonomías, las de autonomía plena (art. 151 de la Constitución Española) y las de autonomía limitada (art. 143 C.E.), pero esta heterogeneidad se puede convertir en homogénea con el trascurso de cinco años, acontecimiento ya producido, lo cual parece propiciar este régimen común, posiblemente realidad, con carácter común, dentro de poco.

El panorama ahora de nuestro interés en relación con el Banco de España, supuesta la asunción de competencias en las materias enunciadas en el art. 148.1 de la Constitución Española, las permitidas por el art. 149.1 además de las no atribuidas expresamente al Estado, las que se llaman habitualmente "materias residuales" (art. 49.3 de la Constitución Española), porque es el Banco el que actúa de interme- 
diario en lo atribuido al Estado, ejercido por el Gobierno y delegado en él. Hemos visto existe un techo competencial en cualquier materia, asumible por las Comunidades Autónomas. La ejecución, la gestión o cualquier otra actividad declarada, o deducida constitucionalmente, nos da un índice referencial, sobre la naturaleza de estas competencias autonómicas, relativas naturalmente a las Cajas de Ahorro, que se debe comparar, para evaluar, con el techo competencial del Banco de España. En concreto las referencias constitucionales son escasas, no directamente alusivas al objeto de nuestra investigación, pero sí muy directamente relacionadas con él.

No existe alusión, en la Constitución Española de 1978, a las Cajas de Ahorro, pero sí una serie de artículos que inciden (21) directa - Indirectamente en las mismas, al establecer un marco jurídico general, como es el principio de libertad de empresa y economía de mercado, la subordinación de la riqueza al interés general, reconociéndose la iniciativa pública en la actividad económica, la planificación de la actividad económica, la actividad y potestad tributaria, la incidencia presupuestaria, manifestaciones del crédito como la Deuda Pública, los derechos y obligaciones, iguales para todos en todo el territorio, etc. y sobre todo el tratamiento competencial en relación con las Comunidades Autónomas, para el fomento del desarrollo económico de las mismas, en el concierto de la política económica nacional, en especial también la competencia exclusiva del Estado sobre la ordenación del crédito, la banca y los seguros, además de la posibilidad de atribución de competencias en materia estatal por las Cortes Generales a todas o a alguna de las Comunidades Autónomas.

Hecho el inciso anterior, sobre la problemática competencial general, necesario para una mejor comprensión e inteligencia del papel desempeñado por el Banco de España en este juego de facultades repartidas y frecuentemente compartidas, a título propio o por adscripción directa y muy generalmente delegada, como hemos visto hace unas páginas, es ocasión de situar las observaciones en torno al protagonismo del Banco de España con varias facetas, polifacético, deducción lógica y natural de una presencia e intervención aceptada por todos, pero actuación enfatizada últimamente en reforzar la solvencia y garantías genéricas del sistema financiero, con medidas rigurosas y

(21) Vide, los artículos $38 ; 128.1$ y $2 ; 131.1$ y $2: 133$ del 1 al $4 ; 134$ del 1 al $7 ; 135.1$ y 2 ; 139. 1; 148. 1. 13ํㅡ y 2; 149. 1. 11․ $13^{\circ}$ y $3 ; 150$ de la Constitución Española de 27 de diciembre de 1978 (BOE del 29) en especial, al objeto de este estudio el art. 149. 1. 110 y 3 , el primer inciso relativo a competencia exclusiva sobre sistema monetario y bases de la ordenación del crédito, banco y seguros, el ap. 3 en las materias no atribuidas expresamente al estado. 
radicales decisiones, como las aludidas de dotar fondos de pensiones $y$ de insolvencia (22).

Es el momento de afrontar un periodo trascendental, podemos decir histórico a nuestros efectos, cual es el de la ordenación del sector crediticio mediante una Ley, en principio ni general ni ordenadora sectorialmente de este ámbito, pero pretexto para hacerlo, se trata de la regulación legal tan repetida de la Disciplina e Intervención de las entidades de Crédito.

Con este instrumento legal se encaran problemas más allá de su título y pretensión inicial: el derecho sancionador en el sector. Como la propia Ley reconoce y la lectura de Preámbulos y Exposiciones de Motivos es fundamental para identificar la intención, justificación y razones, filosofía en definitiva de las normas, pues en el Preámbulo de la de Disciplina, de la cual nos ocupamos ahora, se manifiesta de forma clara, en orden a los atributos competenciales del Banco de España, cómo se ha producido una radical transformación en cuanto a la posición que ocupa, fenómeno no de ahora sino producido hace más de dos décadas, concretamente desde 1962.

En esta lenta pero progresiva transformación, por su propia naturaleza silenciosa, el protagonismo se ha ido acusando de forma notoria y ya nadie discute sea el instrumento que garantiza la unidad del sistema de pagos, como Banco Central y Banco de Bancos, es además responsable de la política monetaria que al no poderse separar de la crediticia supone dirigir la liquidez del total del sistema económico. Con una peculiaridad y es que el Banco de España no es algo ajeno a la banca en general, no está fuera del sistema, está dentro de él y desde el interior del mismo es el quicio alrededor del cual gira y desde la cúspide, en pirámide gráfica, dirige con un criterio y atributo jerárquico superior, pero esta precisión en la que coincidimos con un sector doctrinal (23), no ha sido advertida en la Ley de Disciplina, que sólo la entiende desde una perspectiva de la disciplina en su versión

(22) Vide, Rating, pág. 136, de la Revista Cit. en la colaboración sin autor, bajo el título: "Marco jurídico", donde se hacen estas afirmaciones: "El énfasis que el Banco de España viene poniendo los últimos años en las diferentes actuaciones para reforzar la solvencia y garantías genéricas del sistema financiero ..." , (vide, columna segunda, ap. "fondo de pensiones", pág. cit. 136), cita textual que se subraya con la afirmación en el mismo lugar de que "Las fusiones y los cambios en la normativa propiciados por el Banco de España han reestructurado un marco al que las Cajas se adaptan con grandes esfuerzos" (el subrayado es nuestro).

(23) Vide, "Comentarios a la Ley de Disciplina e Intervención de las Entidades de Crédito". Ed. dirigida por Tomás Ramón Fernández Rodríguez, op. cit, en el Estudio Preliminar: "El ordenamiento crediticio y bancario español: reflexiones después de la crisis", pág. 17, segunda columna, del citado autor dice refiriéndose al Banco de España"... no es algo exterior al grupo organizado de entidades que constituyen el ordenamiento 
supervisión, régimen de supremacía administrativa, con una intensidad superior a la soportada por los demás sectores económicos (24). Esta supervisión se realiza por medio e instrumentando un régimen especial de supervisión administrativa sobre las Entidades financieras, entre las que se encuentran las Cajas de Ahorro, por captar recursos entre un público muy amplio en la mayor parte de los supuestos, sin datos ni conocimiento para evaluar la solvencia de la Entidad en la que deposita además de sus activos financieros su confianza; ahí interviene el Banco de España, para paliar esa carencia y facilitar la confianza a los depositantes, esto se hace pues supone una condición imprescindible para el buen funcionamiento del sistema financiero, ya que las Entidades de Crédito ocupan una posición central, en los mecanismos generales de pago en el país.

Esta es la argumentación de la Ley de Disciplina, siguiendo un criterio a nuestro entender tradicional, no precisa lo afirmado en anterior reflexión, pues de alguna forma da a entender el Banco de España se sitúa en un plano de Administración indiferente, no comprometida, neutral, aparte, es decir no encardinada, como creemos debería haberlo hecho, sino en un plano completamente distinto como poder público distinto, no interesado directamente $y$ menos incluido, aunque con carácter preeminente en lo que comunmente se ha llamado supervisión bancaria, de gran incidencia desde luego y con mayor intensidad que en cualquier otro aspecto, pero elude, creemos intencionalmente, el compromiso y configura al Banco de España como algo diferente, separado de las demás Entidades de crédito, aunque como consecuencia también le distancia de los poderes públicos, del Gobierno o del Ministerio de Economía y Hacienda, convirtiéndole en algo externo, exotérico en auténtico sentido y ortografía de la expresión. Es decir así concebido el Banco emisor se le distancia de los tutelados, la banca y Cajas de Ahorro, se le utiliza como intermediario, por delegación y se aproxima, "servata distancia", de aquella concepción hoy superada de 1962, cuando era un "concesionario" de un privilegio, íntimamente ligado a la soberania del poder, a través de sus facultades de monopolio, en torno a la emisión de dinero.

sectorial del crédito y la banca, llamado a vigilarlo desde fuera y a corregir, también desde fuera sus eventuales desviaciones, sino parte de él y parte esencial además, en la medida que, desde dentro del mismo lo vertebra y dirige" (el subrayado es del autor, que reproduce en el texto cit. en bastardilla).

(24) Vide, el preámbulo que como introducción innominada tiene la Ley 26/1988, de 19 de julio (BOE del 30), sobre Disciplina e Intervención de las Entidades de Crédito, que desde el principio plantea el tema en el párrafo primero, en el segundo incide machaconamente en la supervisión y al final enfatiza las funciones en el párrafo anterior al antepenúltimo la labor del Banco de España concentrada. 
La realidad nos parece distinta, se regula la cuestión de una u otra forma, pues en el sistema solidario de Entidades de Crédito actúa como última instancia, como vértice o ápice piramidal pero estando dentro y no fuera como parece querérsele configurar. $Y$ esto por razones no formales o de prurito y conveniencia, sino porque es así, pues su carácter central, por eso la acepción correspondiente la hemos resaltado, se impone de forma indudable, al no poderse concebir de otra manera para poder ejercer el respaldo necesario a las demás entidades y en especial a las Cajas de Ahorro.

Esta argumentación desentraña conceptos y aclara preceptos constitucionales, como el imperativo de obligado cumplimiento, el 149.1.11ำ donde se atribuye competencia exclusiva al Estado sobre el sistema monetario y sobre las "bases" de la ordenación del crédito y la banca, no se va a insistir sobre este aspecto, pero se ha de decir que lo esencial, lo básico es cosa del Estado y éste a través del Gobierno vía Ministerio de Hacienda, con intervención del Banco de España lo determina, con lo cual se aclaran enigmas, confusiones, ambigüedades y hay una parcela de seguridad, sin correr el riesgo de que cada una de las Comunidades Autónomas, en diecisiete supuestos distintos, lo entienda cada una a su manera.

¿Qué reflexión general nos ofrece la Ley 26/1988, de 29 de julio?, naturalmente en relación con el Banco de España y en la configuración de éste, para incidir sobre las Cajas de Ahorro. No puede ser otra que la de haber tratado, por alusiones, desde el Preámbulo, articulado (48 artículos) y disposiciones adicionales transitorias y derogatoria, el asunto competencial o bien directamente o en tangente, pero con incidencia.

Ya hemos precisado la relevancia que el introito de la Ley le da al Banco de España, implícitamente pero también explicitado su pensamiento y filosofía: "concentración en el mismo de las funciones de registro, control e inspección de todas la entidades de crédito, así como de las sociedades de garantía reciproca" (25).

(25) Vide, la introducción de la ley 26/1988, de 29 de julio, de Disciplina e intervención de las Entidades de Crédito, que desde los primeros párrafos está implícitamente refiriéndose al papel desempeñado por el Banco de España pero al final como resumen hace la cita del texto entrecomillado, que a continuación justifica en tres motivos, que antes hemos examinado en el apartado correspondiente. No obstante, sería interesante que a la manera del fallido Proyecto de Ley de Funciones del Banco de España, se hubiera precisado exactamente cuáles eran éstas. la paradoja aparece aquí también, la Ley tiene obsesión por el protagonismo del banco de España y acaba sin una precisa y clara definición de sus funciones, postura y situación del mismo en el sistema. 
Un simple recorrido secuencial, con una lectura detenida del articulado, de sus cuarenta y ocho artículos, once citan de forma expresa y en las cuestiones más importantes, al Banco de España.

La primera alusión es a las circulares en el primer artículo de la Ley, al considerar normas de ordenación y disciplina a las mismas (26).

Después de regularse el régimen sancionador en general y las infracciones y sanciones, aparece otra vez una expresa referencia al Banco de España, al normarse las competencias en la materia (27), atribuyéndose una facultad de propuesta a nuestro entender más importante que lo aparentemente prescrito, pues concurren de hecho y por juego de lo dispuesto las facultades de instrucción y resolución en los expediente incoados por infracciones graves y leves. Aquí seria posible cuestionar, por inconstitucional, declarado en la Sentencia num. 145/1988, de 12 de julio, el que el juez sea instructor y a la vez sentencie, no obstante se debe considerar la materia es distinta el juez constitucional centra su sentencia sobre materia penal y además la atribución, aquí en el supuesto del Banco de España sus funciones de instrucción y resolución no se atribuyen a los mismos órganos aunque pertenezcan al mismo Banco.

Al regularse las sanciones, se contemplan tres tipos de intervención del Banco de España moduladas en cada supuesto: sanciones ejecutivas, resoluciones que pongan fin al procedimiento con la posibilidad de ser recurribles en alzada ante el Ministro de Economía y Hacienda lo que convierte a éste en un superior jerárquico nato legalmente el supuesto de sanciones impuestas por el Banco de España no ejecutivas, hasta que sean firmes por vía administrativa (28).

La posibilidad de imponer multas coercitivas, cuando la sanción consista en la constitución de depósitos compensatorios no remunerados, es otro de los aspectos concretos referidos en la Ley de Disciplina

(26) Vide, art. 1. 5 de la ley de Disciplina cit. y el comentario de Tomás Ramón Fernández Rodriguez, en op. cit. al art. 1, en especial ap. IV "Clausula legal 'normas de ordenación y disciplina' ", pág. 31 de los Comentarios cit. de la ley. Madrid 1989.

(27) Vide, art. 18, en sus reglas, a), b) y c) de la Ley de Disciplina que declara al Banco de España competente para la instrucción de expedientes (a); para imponer sanciones, lo que equivale a resolver (b) y por último, la facultad de propuestas, en el supuesto de infracciones muy graves $\{c\rangle$; Cfr. José Luis Piñar Mañas, comentario al art. 18, en Comentarios cit. sobre la Ley de Disciplina e Intervención de las Entidades de Crédito.

(28) Vide, art. 25 de la Ley de Disciplina e Intervención de las Entidades de crédito, comentado por César Albiñana Cilveti, en "Comentarios" op. cit. Madrid 1989, págs. 80 y sgts. en sus aps. 1, 1 y 3 donde se contemplan los tres supuestos citados en el texto. 
e Intervención (29). Este medio de ejecución forzosa previsto en la Ley de Procedimiento Administrativo de 17 de julio de 1958, concebido como medio para compeler al sancionado para vencer su resistencia y con la posibilidad de reiterar las multas, con el carácter, aceptado generalmente por la doctrina, de no ser, sanciones, en el sentido de multas-sanciones, sino instrumento con que cuenta el órgano competente, en este caso el Banco de España, para vencer la resistencia del administrado especial, en este hipotético supuesto Cajas de Ahorros, y obligarle, como destinatario de un acto administrativo, a su cumplimiento.

Otro aspecto contemplado legalmente es el de la formulación de requerimientos e imposición de multas por el Banco de España, hasta un determinado limite, cuando sujetos individuales o Entidades, se supone de Crédito, persona física o jurídica, nacional o extranjera, ejerciere en el territorio español, sin previa autorización e inscrita en el Registro correspondiente, actividades reservadas legalmente a Entidades de Crédito, sancionándose también la utilización de denominaciones (entendemos se incluye el uso de logotipos) genéricas propias de aquellas Entidades y otras que puedan inducir a confusión (30), definiéndose a continuación a estos efectos lo que se entiende, en particular, por actividades reservadas legalmente, para evitar el funcionamiento de Entidades Bancarias o de Ahorro, como Bancos de hecho, situaciones irregulares al margen de la legalidad establecida y que han sido en ocasiones producidas, tanto en España como en otros países (31).

En otro sentido, hay alusiones al Banco de España, muy importantes, reguladas en el Título III de la Ley de Disciplina e Intervención, es

(29) Vide, art. 26 de la Ley cit. y comentada, en sus puntos 2 y 3; en el primero se dice que la constitución de depósitos compensatorios no remunerados, se hará en el Banco de España. El punto 3 determina que cuando la sanción (parece un término impropio por no ser tal en sentido de multa-sanción), no fuera cumplida en el plazo señalado, se atribuye al Banco de España la competencia de imponer multas coercitivas.

(30) Vide, el art. 28 de la comentada Ley de Disciplina que fija la prohibición de actividades reservadas y la utilización de denominaciones. El art. 29 del mismo cuerpo legal es el que establece la competencia del Banco de España para la formulación de requerimientos y la imposición de multas, con el requisito de previa audiencia de la persona o entidad interesada, siguiéndose para la imposición de multas el procedimiento establecido en la Ley de Disciplina.

(31) Vide, Sánchez Calero, F. : "La delimitación de la figura de entidad de crédito y la de otros sujetos", en la Revista de Derecho Bursatil y Bancario, núm. 28, octubre-diciembre de 1987, en especial págs. 721 y sgts. , que recuerda casos, de importantes proporciones, de auténticas estafas, a ahorradores y depositantes de buena fe, como el caso Giuffre en Italia o el de Doña Blanca en Portugal. En España recientemente se han dado algunos supuestos similares, tal vez de menor importancia, bajo aspectos como los de inversión filatélica, de los cuales se han hecho eco los medios de difusión y comunicación social. 
este último aspecto: "medidas de intervención y sustitución", son medidas por su propia naturaleza provisionales "hasta, que se supere la situación" (32) y su aplicación es a través de una serie de estándares, como la excepcional gravedad, peligro de estabilidad, liquidez y solvencia, indicios fundados de existencia de gravedad excepcional a través de la contabilidad, incluso que ésta no refleje o pueda deducirse de ella la misma. El único problema consiste en la aplicación de esas circunstancias que es la Administración, en este caso el Banco de España, el que aprecia su existencia utilizando en sentido técnico la discrecionalidad, como unidad de medida tipificadora de conceptos estandar en un momento determinado.

Las citadas medidas por imperativo legal son acordadas por el Banco de España, que actúa como Banco Central, el cual debe dar cuenta razonada de su adopción al Ministerio de Economía y Hacienda. La adopción del acuerdo se hace de oficio o en su caso a petición de parte interesada, entonces debe constar una petición fundada de la Entidad de Crédito, a través de los administradores o por el órgano de fiscalización interna, o una minoría de socios igual al menos a la exigida para instar la convocatoria de una Asamblea o Junta General Extraordinaria, de acuerdo con las normas estatutarias o reglamentarias establecidas, aunque la Ley dice "legislación respectiva" (33). Obviamos hacer más indicaciones, pues no es hora de hacer un comentario en profundidad, sólo considerar la presencia del Banco de España en diversos preceptos del régimen sancionador y supuestos en hipótesis referidos a Cajas de Ahorros, como Entidades de Crédito, las cuales pueden encontrarse por referencia en algunos de los casos citados. Tampoco se hace mención, aunque sí lo establece la Ley, a las características del acuerdo, su

(32) Vide, art. 31 de la Ley de Disciplina que contempla los supuestos de intervención o la sustitución provisional de los órganos de administración y dirección. Sobre la intervención en general Cfr. Hernando Delgado, Justo: "La intervención pública de Empresas privadas", en el libro Homenaje a Garcia Trevijano-Fos, Ed. por el CUNEF e IEAL, Madrid 1982, págs. 710-744, que es un estudio general de la intervención, relacionado con su reconocimiento constitucional, donde el autor hace una consideración final (págs. 730-732) en f) apartados donde se resumen su opinión, haciendo hincapié en las garantias que conllevan estas medidas cuya implantación debe responder a una situación excepcional.

(33) Vide, art. 32 de la Ley de Disciplina que dice: "1. Las medidas de intervención o sustitución a que se refiere el articulo anterior se acordarán por el Banco de España. dando cuenta razonada de su adopción al Ministerio de Economía y Hacienda" (el subrayado es nuestro), en el punto 2 se contempla el supuesto en caso de instancia de parte. Hay pues que relacionar el art. 31, en sus tres apartados y supuestos con el art. 32 , que regula el procedimiento de adopción de medidas de esta naturaleza. 
naturaleza ejecutiva, su publicidad e incluso las consecuencias, expeditivas por demás: "... podrá llegarse a la compulsión directa para la toma de posesión de las oficinas, libros y documentos correspondientes o para el examen de estos últimos" (34), naturalmente recurrir a estos medios de ejecución forzosa, previstos en los arts. 104 y 108 de la Ley de Procedimiento Administrativo, tendrán obligadamente una referencia atendiendo a la necesariedad y proporcionalidad de la medida, exigencias obvias en esta extremosa actitud de la compulsión.

Sobre esta misma rúbrica y caracterización de las medidas de intervención y sustitución la figura del Banco de España vuelve a aparecer, pues es éste quien acuerda el cese de la medida de sustitución (35), regulándose las operaciones en el interregno; cese de la medida y normal restablecimiento del funcionamiento de la Entidad de Crédito. Si el Banco de España legalmente acuerda, en consecuencia congruente decide el cese, con un automatismo reglado también por la Ley, cuando se supere la situación, luego lo único que se hace, en automatismo, es actuar al dictado de las circunstancias y acordar la situación se ha normalizado y han de realizarse determinadas actividades, encaminadas al restablecimiento de la normalidad.

Un cariz importante, al que por ahora no podemos dedicar la merecida reflexión pero sí subrayar su trascendencia, es el enunciado por la propia Ley como "disposiciones complementarias", donde parece por epigrafía van a regularse aspectos accesorios, en su terminología de complemento y añadido y no es así, por su entidad de gran trascendencia en todos los sentidos y más aún en los referentes a la relación Banco de España/Cajas de Ahorro, como son la modificación del Real Decreto Legislativo 1298/1986, de 26 de junio, de adaptación del derecho vigente en materia de establecimientos de crédito al de las Comunidades Europeas, donde se definen y ahí están las Cajas de Ahorros y la Confederación Española de Cajas de Ahorros, sin embargo no se hace cita expresa a las Federaciones de Cajas, establecidas en gran parte de las Comunidades Autónomas en su legislación sectorial específica

(34) Vide, art. 34.3 in fine de la Ley de Disciplina.

(35) Vide, art. 37 de la Ley de disciplina e Intervención de las Entidades de Crédito. Textualmente se dispone: "Acordado por el Banco de España en el cese de la medida de sustitución, los administradores provisionales procederán a convocar inmediatamente la Junta General o Asamblea de la entidad de crédito, en la que se nombrará el nuevo órgano de administración. Hasta la toma de posesión de éste, los administradores provisionales seguirán ejerciendo sus funciones" (el subrayado es nuestro y se hace para resaltar la intervención expresa del Banco de España). 
(36) o la responsabilidad administrativa de los miembros de las Comisiones de Control de las Cajas de Ahorros y sobre todo al aspecto competencial.

Cuando se resalta la competencia del Banco de España para la instrucción de expedientes sancionadores, se excepcionaba lo dispuesto en el art. 42 de la Ley de Disciplina, con la fórmula de estilo: "sin perjuicio de" (37) y es ahora cuando nos referimos a este importante aspecto definidor, en concurrencia con las Comunidades Autónomas, en colaboración con las mismas, declarando básicos los preceptos contenidos en determinados títulos de la Ley de Disciplina.

En esta configuración del Banco de España, la Ley de Disciplina nos sigue ofreciendo rasgos tipificadores y uno significativo es el de concebirle en la escala jerárquica, en orden a la autorización para la creación de todas las Entidades de Crédito, un puesto subordinado ante el Ministro de Economía y Hacienda (38), como actor en la ordenación, control e inspección de las referidas Entidades así como el responsable de su registro, significándose igualmente la posibilidad de convenir con las Comunidades Autónomas.

Así pues los rasgos característicos ahora ofrecidos nos perfilan y matizan al Banco de España en muy diversos sentidos, en especial en cuanto a potestades administrativas, pues interviene con un informe para la autorización de creación de todas, no de algunas o de unas pocas o con excepciones, la inteligencia de lo dispuesto en la Ley de

(36) Vide, art. 39 de la Ley 26/1988, de 29 de julio, sobre Disciplina, donde se modifica el título del real Decreto Legislativo 1298/1986, de 26 de junio, el art. $1^{\circ}$ da una definición, a los efectos de la disposición, de entidades de crédito, y se conceptúan en particular como tales una lista en $\mathrm{h}$ ) apartados, como "numerus clausus". En cuanto al tema responsabilidad de los miembros de las Comisiones de Control, Vide el art. 40, sobre el que se han hecho reflexiones en el texto.

(37) Vide, art. 42, en relación con el 18 de la Ley de Disciplina, que en sus 7 puntos su comentario podria ser objeto de un estudio monográfico. Vide, Martín Oviedo, José Maria: "Ordenación legal del sistema financiero español". Civitas, Madrid 1987; Cuervo Garcia, Parejo Gámir y Rodríguez Saiz: "Manual del sistema financiero. Instituciones, Mercados y Medios en España". Ed. Ariel, Barcelona, 2ª edición, 1988, como obras generales de necesaria consulta al respecto.

(38) Vide, el trascendental art. 43 de la Ley de Disciplina, pues en él se significan los aspectos de informe para la autorización de creación de todas las entidades de Crédito (art. 43. 1), además de corresponderle el control e inspección de todas las Entidades de Crédito (art. 43. 2, inciso primero), el control e inspección de la aplicación en general de la Ley 2/1981, de 25 de marzo (art. 43. 2, inciso segundo), para reiterar la competencia del Banco de España, el registro, control e inspección (art. 43. 3), para establecer la jerarquia aludida en el texto por medio del recurso de alzada ante el Ministro de Economía y Hacienda (art. 43. 4), finalmente en relación con la LORCA, se habla de la capacidad de celebrar Convenios y lo indispensable de la inscripción en los registros del Banco de España (art. 43. 5). 
Disciplina, en este aspecto no es sólo esta capacidad de informe, bastante más importante de lo que a primera vista parece y al que nos hemos referido antes. Pero hay referencias al control e inspección de cualquier entidad de crédito, pues la expresión legal es de "todas", así como su inscripción, el registro que se asocia al referido control e inspección, en el supuesto de otras entidades, como son las Sociedades de Garantía recíproca y de Reafianzamiento, este poder público del Banco de España se entiende sin perjuicio de las competencias de las Comunidades Autónomas y de lo que resulte de los Convenios celebrados entre ambas organizaciones. La facultad de inscripción se establece como indispensable en los registros del Banco de España.

En esta cuestión, reglada por el art. 43 de la Ley de Disciplina, se plantea la tradicional tensión entre el Banco de España y el Ministerio de Economía y Hacienda, así como la de la Administración del Estado y las Comunidades Autónomas.

Otro cariz también tenido en cuenta por la regulación legal de la disciplina es el deber de colaboración, aquí no se cita expresamente al Banco de España, pero por la descripción, Organismo encargado del control de cambios y de la vigilancia de los delitos monetarios, aquél es aludido (39).

Un matiz, también importante, es la intervención del Banco de España, respecto de la habilitación legal por parte del Gobierno para establecer y modificar el capital social y la dotación inicial de mínimos que las Entidades de Crédito deben tener suscrito (40). Aquí la participación del Banco emisor es de informe previo.

El último supuesto en que la Ley de Disciplina e Intervención de las Entidades de Crédito hace mención expresa al Banco de España, se produce también en el último articulo de los que la Ley tiene, donde se contempla, después de la habilitación legal en favor del Ministro de Economía y Hacienda, la encomienda al Banco de España (41), en relación con el establecimiento y modificación de las normas de

(39) Vide, el art. 45 de la Ley de Disciplina que dice: "Las entidades autorizadas quedan sujetas al deber de colaboración con los Organismos encargados del control de cambios y de la vigilancia de los delitos monetarios" (se subraya por nosotros). El monopolio estatal de la tenencia y comercio de divisas, establecido por la Ley 40/1979, de 10 de diciembre, sobre Régimen Jurídico de Control de Cambios, y encargándose al Banco de España del mismo, en este sentido ha de tenerse tambièn el Real Decreto $2402 / 1980$, pero no sólo es deber sin reacción muy grave el incumplimiento del deber citado.

(40) Vide, art. 47. 1. a) de la Ley de Disciplina e Intervención cit.

(41) Vide, art. 48 de la Ley de Disciplina que en su apartado 1 faculta al Ministro de Economia y Hacienda para establecer y notificar las normas de contabilidad y los modelos a que deberá sujetarse el balance y la cuenta de resultados de las Entidades de Crédito. 
contabilidad y los modelos a que deben sujetarse el balance de cuentas de resultados consolidados, previstos en la Ley 13/1985, de 25 de mayo (Ley de coeficientes de inversión, recursos propios y obligaciones de información de los intermediarios financieros) (42).

En el régimen adicional y transitorio, en las disposiciones respectivas, se encuentran una serie de indicaciones que contemplan la intervención del Banco de España de una u otra manera, por lo cual se impone la necesaria observación sobre las mismas, para finalizar en reflexión este escorzo, sobre la entidad bancaria central desde una óptica disciplinaria y de su ley ordenadora, disquisiciones tal vez demasiado premiosas, pero al tiempo y por contraste extensas, ya que las referencias son constantes, reiteradas bajo los más diversos aspectos y no sólo, como se ha podido constatar, en el lógico disciplinario.

La disposición adicional primera, redacta varios artículos, en una nueva versión, de la Ley 33/1984, de 2 de agosto, sobre Ordenación del Seguro Privado y en esta nueva redacción es donde encontramos precisas referencias al Banco de España, al regularse las sanciones (43), haciéndose hincapié en la competencia atribuida al Banco de España por la propia Ley de Disciplina.

Sobre la obligación de información al Banco de España, en la forma que determine el Gobierno, en relación sobre la composición del accionariado o de las alteraciones producidas, se ocupa el texto de la disposición adicional segunda, como también contempla la legitimación de aquél, para promover la impugnación de acuerdos y la obligación de comunicarle cualquier participación en el capital, que de forma directa o indirecta suponga la titularidad o el control del $5 \%$ o más del capital social de una entidad de crédito (44).

(42) Vide, la Ley $13 / 1985$, de 25 de mayo (BOE del 28 ), sobre coeficientes de inversión, recursos propios y obligaciones de información de los intermediarios financieros. Vide, art. 12 y la derogación que hace la Ley de Disciplina del mismo. Es interesante la disposición derogatoria, que contiene una importante tabla de derogaciones en relación con las Cajas de Ahorros, fijándose incluso el alcance total o parcial de las derogaciones realizadas.

(43) Vide, disposición adicional primera de la Ley 26/1988, de 29 de julio, de Disciplina e Intervención de las Entidades de Crédito. Al darse nueva redacción al art. 44 "Sanciones" de la Ley 33/1984, de 2 de agosto, sobre Ordenación del Seguro, en el ap. 2 del art. 44 cit. se hace la mencionada referencia al Banco de España, citándose su ámbito competencial. Vide, también disposición adicional $1^{\mathrm{B}}$. $8^{\circ}$.

(44) Vide, sobre la disposición adicional segunda de la Ley $26 / 1988$, reiteradamente citada, los "Comentarios" op. Cit. dirigidos por Tomás Ramón Fernández, el comentario de Jaime Aguilar Fernández-Hontoria, págs. 167 y sgts. de la obra colectiva. En la disposición adicional cit. véanse los puntos 1 sobre información y 4 sobre la comunicación de alteración en la participación del capital social y en el penúltimo inciso de este número la legitimación del Banco de España para impugnación de acuerdos sociales, según la normativa reguladora de la Ley de Sociedades Anónimas. 
Los anteriores aspectos e intervenciones se encuentran justificados en el interés público en relación con la composición del capital de las Entidades de Crédito, así como las consiguientes obligaciones de información acerca de la composición de su capital y de su participación en el capital de otras entidades de crédito, asi también se establece respecto de la adquisición de participaciones significativas en el capital, la impugnación de los acuerdos citados se produce en caso de incumplirse la obligación de información, entonces la autoridad monetaria se encuentra autorizada para iniciar el expediente sancionador correspondiente. Claro es que la obligación administrativa de información (punto 4 de la disposición adicional segunda) debería contar con un mecanismo administrativo de garantia para su efectividad y de reacción en el supuesto de incumplimiento.

La modificación de la Ley de Ordenación Bancaria de 31 de diciembre de 1946, realizada por la disposición adicional tercera de la Ley de Disciplina (45), supone una reformulación de la forma de intervención a través de autorizaciones situando el énfasis en el Banco emisor, que en la Ley de Ordenación Bancaria no estaba presente, por entenderse entonces que el Banco de España era una Entidad privada, concesionario de un privilegio: la emisión, naturaleza que permanece en 1962, en la Ley de Bases de Ordenación del Crédito y la Banca, a pesar de que en este momento se le reprocha no haberse convertido en un Banco de Bancos y Central (46), aunque sin embargo no

(45) Vide, la disposición adicional tercera de la Ley de Disciplina, que da nueva redacción al art. 48 de la Ley de Ordenación Bancaria de 1946. Contrastando los textos, el antiguo u el renovado, se ve la presencia importante del Banco de España, en especial en los núms. 1 y 3 del modificado art. 48 , reiterando lo establecido en la disposición adicional anterior.

(46) Vide, el Preámbulo de la Ley 2/1962, de 24 de abril (BOE del 16), verdadera exposición histórica de lo acaecído en cada momento con el Banco de España, donde late una denuncia, vista la evolución, el no haber llegado a ser un Banco Central, regulador del mecanismo crediticio, pero incongruentemente el texto de esta Ley le niega la instrumentación suficiente para serlo, lo cual tampoco hace, al seguir en la misma línea, el Decreto-Ley 18/1962, de 7 de junio (BOE del 13), de nacionalización y reorganización, pero al convertirle en entidad pública autónoma, permite una evolución de hecho, configurándose dia a dia como tal, con una normativa de menor rango al legal, por vía de delegación del Ministerio de Hacienda hasta llegar a 1971, con la Ley sobre Ordenación y Régimen del Crédito Oficial d 19 de junio de 1971, donde hay ya transferencia de funciones sectorial importante. El proceso se habia iniciado antes en los Decretos-Leyes de 29. 11. 1962, que iniciaron el proceso de autorización al Ministerio de Hacienda para delegar a favor del Banco de España aquellas facultades que el competen en orden al control y disciplina de la banca privada, proceso culminado como hemos visto en la Ley de 1988 de Disciplina e Intervención de las Entidades de Crédito. 
se le dan los medios necesarios para la implementación de una actividad de esta naturaleza, lo que se hace con posterioridad, por vía de hecho, formalmente justificada y mediante normas de delegación, proceso que continúa a lo largo de dos décadas y ya en el pasado año (1988), eventualmente finaliza el proceso, aún no cerrado pues estimamos sería necesaria una disposición legal del tenor de la non nata Ley de Funciones del Banco de España, que esclarecería y pondría en su sitio la cuestión, sobre todo en orden y cara al mítico año 1992, en torno a la liberación en el concierto europeo, donde y cuando han de estar precisados determinados temas, como el de los Bancos Centrales, significándose su papel dentro de los poderes del Estado, pues con excepciones falta una profundización sobre el tema (47). Esta cuestión nos parece una auténtica asignatura pendiente, de inmediata y próxima evaluación y contraste donde habrá de contestarse sin dilaciones, adoptándose postura en claridad y evidencia, ante proposición importante y definitiva exigida ya, pero urgida dentro de poco, pues no es posible una dilación más o esperar acontecimientos.

En la disposición adicional octava, en su dos párrafos, hay alusiones importantes al Banco de España y en nuestro interés trascendentales, pues se produce una declaración habilitadora para "el adecuado ejercicio de las competencias que le atribuyen esta u otras leyes" (48), naturalmente con condiciones: primero, que su capacidad de dictar disposiciones necesarias es en el ámbito del desarrollo o ejecución y en segundo lugar, cuando las normas de referencia le habiliten de forma expresa. Con la inclusión de este precepto adicional Se debe a dar una cobertura a los poderes normativos del Banco de España, además de normalizar el vehículo usual "circulares", en precario de cierta forma por sus caracteres y forma de publicación, que hemos examinado en el anterior apartado $y$ a lo dicho allí nos remitimos ahora, para mayor comprensión de estas observaciones y precisiones.

La evolución de los poderes normativos del Banco de España ha sido tratada con inteligencia por un sector doctrinal, incidiendo desde 1946 hasta la actualidad de muy distinta forma y configurándose en

(47) Vide, Sala Arquer, J. M. : "La posición juridica del Banco Federal Alemán" en Revista de Derecho Bancario y Bursatil, núm. 18, Madrid 1985, donde pone de relieve esta ausencia de estudio profundo sobre los Bancos Centrales en Europa, sólo en Alemania en la R. F. A. se ha realizado esta tarea como excepción.

(48) Vide, la disposición adicional octava de la Ley de Disciplina que prescribe: "EI Banco de España, para el adecuado ejercicio ...leyes podrá dictar las disposiciones necesarias para el desarrollo o ejecución de la regulación...". Se subrayan las expresiones recogidas en el texto y la singularidad de la habilitación. 
silencio esta facultad desde 1962, al convertirse en una Entidad de Derecho Público (49).

La obligación del Banco de España de informar anualmente a las Cortes Generales, mediante una memoria de sus actuaciones en materia de disciplina e intervención (50), es una medida adecuada y en línea por lo ya prescrito en la Ley de Organos Rectores del Banco de España, Ley 30/1980, de 21 de junio (BOE del 27), que ya preveía entre las competencias del Gobernador del Banco de España la de representación ante las Cortes y el Gobierno, para lo cual podrá ser requerido por el Congreso de los Diputados, o por el Senado e incluso por cualquiera de sus comisiones, para informar de la ejecución de la política monetaria o crediticia, igual disposición se aplica a las reuniónes del Gobierno en Pleno o en Comisión Delegada.

Se deben hacer algunas indicaciones relativas a los poderes normativos del Banco de España, no habituales por las variables circunstancias en que el ordenamiento financiero se desenvuelve, aplicar a este panorama una dogmática tradicional no sirve, pero sí establecer unas reglas de juego para el ejercicio de esa potestad, lo cual deviene en el establecimiento de unos límites y esa disponibilidad y facultad, compartida con el Gobierno, al cual se le reserva constitucionalmente la fijación de los objetivos generales de la politica del crédito y monetaria y su instrumentación es atribuida al Banco Central, que realiza su función como estime más adecuado, en cada momento, para alcanzar los fines perseguidos en especial la salvaguardia del valor del dinero (51).

(49) Vide, Tomás Ramón Fernández Rodríguez, en el Comentario al precepto ahora examinado, en la obra colectiva antes citada "Comentarios a la Ley de Disciplina...", págs. 184 y 185, que parte de un estudio desde un punto cero, la Ley de Ordenación Bancaria de 1946 y llega hasta 1988 con la Ley de Disciplina, donde justifica (pág. 184, primera columna) las tensiones producidas en relación con los poderes normativos del Banco de España, donde se ha llegado a cuestionar, por imperativo del art. 97 de la Constitución Española de 1978, la constitucionalidad de los mismos.

(50) Vide, el párrafo segundo de la disposición adicional octava de la Ley de Disciplina, cuyo tenor es como sigue: “El Banco de España enviará anualmente a las Cortes una Memoria de las actuaciones que hayan dado lugar a las sanciones muy graves y a intervenciones o sustituciones a que se refiere el Título III de esta Ley", precepto lo suficientemente explicito como para hacer otro comentario adicional, relacionado con lo dispuesto en el art. $7^{\circ}$ de la Ley 30/1980 sobre competencias del Gobernador del Banco de España, que precisa sus obligaciones de comparecencia ante las Cortes y el Gobierno.

(51) Vide, la cit. Ley 30/1980 de Organos Rectores del Banco de España, en donde se ve clara la diferencia entre éste y la Administración del Estado, desde el artículo primero de la misma que efectúa este desdoblamiento. Que un mismo texto legal se puede desarrollar en parte el Gobierno y en parte por el Banco de España es de tal evidencia que se hace en pacifica connivencia y es ejemplar al respecto la ley de Coeficientes de Caja, Ley 26/1983, de 26 de diciembre (BOE del 27), que en su artículo sexto ordena: 
La situación descrita no es típica ni peculiar de nuestro régimen jurídico, se produce en todos los países de nuestro entorno, concretamente en los de la Comunidad Económica Europea (52). No es ahora momento de examinar la evaluación y momento actual en el Derecho comparado europeo, pero sí la de afirmar no existe disonancia entre la regulación española y las demás referidas, las causas y situaciones son semejantes, hay un cierto rechazo inicial, como entre nosotros, a que el Banco Central ejerza sin más poderes normativos, al considerársele fuera de la Administración Pública, como lo está, el paliar esta situación diciendo que dichas Entidades son públicas dista bastante de satisfacer, sobre todo a una doctrina rigurosa. Por eso han buscado fórmulas que solapan esta aparente intervención interna atribuyéndose a una Comisión Nacional, o de Control de Bancos, gran parte de estos poderes normativos, pero detrás se cuenta con la intervención y participación decisiva de las autoridades o autoridad superior del Banco de Bancos, o comunmente Banco Central y entre nosotros de España, por lo cual es difícil averiguar dónde está la última autoridad en materia de crédito y política monetaria y si en definitiva, sólo se guardan las formas y aunque formalmente sea un órgano colegiado, cualesquiera sea su denominación, a veces la realidad es que se trata de un simple ejecutor de decisiones adoptadas por aquel Banco.

De esta situación descrita es un claro ejemplo Francia (53),

“El Banco de España fijará los niveles de los coeficientes de Caja y establecerá los métodos para su cómputo, de acuerdo con los objetivos de la politica monetaria señalados por el Gobierno".

Vide, la Ley de Bases de 1962, que inicia este proceso y por razones técnicas, expuestas en su Preámbulo encomienda la ejecución de la política que se siga al Banco de España.

(52) Un inteligente estudio de la situación nos lo ofrece Tomás Ramón Fernández, en sus "Comentarios", op. cit. , Madrid 1989, al hacer un estudio en el comentario a la disposición adicional octava de la Ley de Disciplina, págs. 184 y sgts. de la op. cit. colectiva, repetidamente recensionada, en su ap. III. "La simultánea evolución del Derecho comparado" (pág. 185), describe pormenorizadamente el estado de la cuestión en Francia, en Italia, en Bélgica y en Suiza y por comparación en España. LLega a la conclusión de que por circunstancias históricas concretas obligan en estos paises a dar rodeos que apenas aciertan a enmascarar la real situación ya resuelta entre nosotros al configurarse desde 1962 el Banco de España como una Entidad de Derecho Público, parte integrante de la autoridad monetaria y desde 1980, con una autonomía funcional efectiva.

(53) Vide, la Ley francesa de 2 diciembre de 1945, según la cual el Consejo Nacional del Crédito en Francia ejerce sus atribuciones por intermedio del Banco de Francia. La doctrina a veces mantiene que el Banco de francia no dispone de un poder reglamentario. Vide, Savy y Fromout: "L'intervention des pouvoirs publics dans la vie economique". Tome I, Institutions et politiques P. V. F. , Paris 1978, cit. por Tomás Ramón Fernández, en art. cit. nota anterior, pero este tratadista francés según nuestro autor, el propio Savy en su Derecho público económico, un año antes publico, mantenía la tesis contraria. 
donde el Consejo Nacional del Crédito y la Comisión de Control de Bancos, por la intervención del Gobernador del Banco de Francia y su situación preeminente en ambos órganos, es decisiva y de hecho el Consejo Nacional del Crédito se limita a aprobar las decisiones adoptadas por el Banco de Francia, ponemos este ejemplo pues con matices es válido y referible a los demás paises europeos.

Para paliar, de alguna forma, el estado de las potestades normativas de los Bancos Centrales, existe una corriente de opinión, que a las comunmente denominadas Instrucciones, entre nosotros Circulares, les atribuye un carácter de normas internas, válidas únicamente dentro del ordenamiento sectorial crediticio y bancario, pero esto se puede sustentar en momentos de pacífico desenvolvimiento y en épocas sin problemas, pero en situaciones como las acaecidas últimamente de crisis, inflación ya crónica, paro generalizado, lo cual ha obligado a que se hayan utilizado con mayor intensidad y extensión estos poderes y facultades normativos, en principio deslindados, pero después con superación de los límites establecidos, por razones obvias de necesidad se ha tenido que recurrir frecuentemente a mecanismos de autoridad y con efectos no ya propiamente internos sino externos, de los que tenemos múltiples ejemplos entre nosotros (54). Pero la situación en nuestro país es clara a nuestro entender, no se necesitan ambages pues legalmente el Banco de España es una Entidad de Derecho Público desde 1962 y forma parte de la autoridad monetaria desde 1980, como hemos visto, por tanto no es obligado recurrir a rodeos y se puede afirmar comparte con el Gobierno y la Administración del Estado potestades públicas, habilitadoras para producir, en ciertos límites establecidos y enunciados, una función normativa general de desarrollo y ejecución.

El Ministerio de Economia y Hacienda, en el régimen adicional, de trascendencia, como hemos intentado poner de relieve, tiene unas competencias, respecto de personas físicas o jurídicas que sin estar inscritas en los registros administrativos legalmente previstos, ejerzan operaciones financieras, dichas atribuciones se refieren a "realizar, por sí o a través del Banco de España, las inspecciones que se consideren necesarias a efectos de confirmar la veracidad de la

(54) Esta afirmación es demostrable recientemente, en cualquier oficina bancaria y por supuesto en todas las Cajas de Ahorros en sus Oficinas, hay siempre un anuncio, visible al público, de obligado cumplimiento, donde una norma Circular, presenta con mayor o menor relevancia, cita la norma 3, ap. 7 de la Circular del Banco de España núm. 15/1988 con la advertencia: "Disponible para el público, la tarifa de Comisiones, condiciones y gastos repercutibles" 
información ..." (55), en relación con la contabilidad, actividades financieras, con la periodicidad que se estime necesaria o cualquier otro aspecto, si no se facilita o en su caso hay negativa o resistencia a las actividades inspectoras se sanciona como falta muy grave.

Todas las anteriores disposiciones adicionales, cuya mención se ha hecho, de la segunda a la doce, tienen el carácter de bases de la ordenación del crédito (56), si bien muchas de ellas no contienen normas de ordenación bancaria "stritu senso", al regular cuestiones colaterales, relacionadas, de indole fundamentalmente mercantil, donde los títulos competenciales de la Administración del Estado, suponiendo una competencia exclusiva de la misma no limitada a la regulación de lo básico, habrá que hacer esta excepción y en determinados casos, examinar pormenorizadamente cada una de las disposiciones, por ejemplo la regulación del arrendamiento financiero aquí reglado como disposición adicional (7), es una típica de las que se pueden incluir y salvar de este régimen básico, su estudio excede de la intención y reflexión ahora realizada.

En el régimen transitorio se encuentra una disposición de este talante, a nuestros efectos fundamental, en el que por expreso mandato de la Ley de Disciplina, el Banco de España, en el plazo de un año aprobará y publicará un texto refundido con las disposiciones vigentes (57).

Este sistema de refundición de textos, como el de este supuesto, recuerda a la delegación legislativa, prevista constitucionalmente, si bien en un rango inferior, pues las Circulares con normas y disposiciones generales habitualmente, pero no con ropaje, efectos y trascendencia de los Decretos legislativos (58).

(55) Vide, disposición adicional décima 1. b), que reproduce el primer inciso del entrecomillado en el texto, por referencia al ap. a) de este núm. 1 de la disposición adicional. En cuanto a la reacción por incumplimiento, se contempla en el núm. 2 de esta disposición.

(56) Vide, disposición adicional decimotercera que prescribe: "Las anteriores disposiciones adicionales segunda y duodécima tendrán el carácter de bases de la ordenación del crédito en la medida en que su contenido no derive de otros títulos determinantes de la competencia del Estado" (el subrayado nos corresponde), Luego la salvedad realizada obliga a una labor de hermenéutica.

(57) Vide, disposición transitoria tercera de la Ley de Disciplina e Intervención de las Entidades de Crédito, que confirma en su primer párrafo la vigencia de las Circulares hasta el momento, dándoles un voltaje de actualización e intensidad obligatoria notable, con una condición, la de la transitoria octava ya comentada. el segundo párrafo es un imperativo de refundición, cuyos caracteres se examinan en el texto.

(58) Vide, la Constitución, que en su art. 82 contempla la delegación legislativa, y los requisitos en su núm. 5 respecto a la refundición de textos legales, en donde se establece el ámbito y caracteres de la refunción. en este caso evidentemente no se trata de este supuesto, pero por analogia y en menor nivel, por Ley, se hace lo mismo. No obstante el mantenimiento de las Circulares anteriores, en cuanto a su vigencia, parece un tanto ociosa, aunque tal vez necesaria, para evitar susceptibilidades, pues la doctrina del Tribunal Constitucional a partir de la Sentencia de 8 de abril de 1981, es clara en este sentido, en cuanto a la validez de las normas anteriores. 
Sin embargo las caracteristicas son las mismas de la delegación legislativa, cumpliendo los tres requisitos "sine qua non", de a un órgano en concreto: el Banco de España, por un tiempo determinado: un año y sobre una materia: la tratada con anterioridad por dichas Circulares. Ocurre sin embargo no supone el precepto una convalidación de las Circulares anteriores a la Ley de Disciplina, ni menos todavía una potenciación, una elevación de rango de las mismas, la intención ponderada se nos ocurre es aclaratoria, en el sentido de las potestades normativas del Banco de España, reguladas ahora por la disposición adicional octava, por lo cual no se puede interpretar a partir de este momento no se tengan en cuenta las ejercidas con anterioridad a la publicación de la Ley.

No se hacen observaciones a la derogación que se determina en la Ley de Disciplina, ejercicio en discurso doctrinal interesante, pero de poca o nula trascendencia en el objeto de este trabajo.

Después de esta larga y en ocasiones premiosa lectura y reflexión competencial del Banco de España, desde un punto de vista de la disciplina y ordenación del crédito y de los responsables, agentes ejecutores y también intermediarios financieros en el mismo, se deben hacer las pertinentes observaciones a lo tratado en relación con las competencias normativas del Banco de España, claro es con la imposición de evitar naturales repeticiones, aunque a veces sea imposible no hacerlas, dada la magnitud del problema, la susceptibilidad en relación con el mismo y el estado actual de la cuestión, bastante clarificado, a nuestro entender, después de la Ley de Disciplina e Intervención, que bien podría haber obviado el tema, pero sin embargo aborda el problema y si no lo resuelve a gusto de todos, al menos fija unos criterios básicos y también importantes para el justo entendimiento de esta importante rúbrica, como hemos visto en alusiones inmediatamente anteriores, a esta nueva parcela de disquisición.

A manera de resumen y dado por supuesto lo anteriormente dicho se evidencia un hecho, la importancia de los poderes normativos del Banco de España, ejercidos normalmente a través de Circulares, cuyas normas e instrucciones, de obligado cumplimiento gravitan sobre los intermediarios financieros, cualesquiera que sea su naturaleza, importancia, carácter e incluso, como se ha visto, incide sobre aquéllos que incluso no tiene un reconocimiento $y$ han sido registrados como tales.

Por supuesto las Cajas de Ahorros son destinatarios, tanto cuantitativa como cualitativamente, cualificados de esta previsión normativa y a ellas se refieren con frecuencia estas potestades públicas atribuidas al Banco Central que también lo es de Cajas de Ahorro, 
aspecto en el que no se ha insistido demasiado quizá por ser obvio, pero es interesante resaltar pues si no en ocasiones puede ser olvidado.

Para completar este capítulo seria necesario hacer las pertinentes observaciones que la Ley de Disciplina hace a las Cajas de Ahorros, importantes por su especificidad y a las que no hemos dedicado epígrafe alguno, pero como necesario complemento al reflexionar ahora debemos reparar sobre ellas, si bien con una sintesis para no alargar en exceso la digresiones, pero para también hacer el reparo necesario, bajo la formulación al menos indicativa de los temas pendientes, o los presentes tratado recientemente y desde una óptica legal. Tema intimamente ligado con los poderes normativos, pues por referencia se ejercen en razón a la configuración caracteres, sujeción y dependencia de las entidades financiera objeto de este estudio: Cajas de Ahorros, con un punto de mira inexcusable el Banco de España.

Renunciamos, pues haria prolija la cita, a aquellas previsiones, que son muchas, de la Ley de Disciplina e Intervención, a las Entidades de Crédito, entre las cuales están, evidentemente, las Cajas de Ahorro y hacemos notoria sólo la especial mención de la voz relativa a las mismas y recogidas en el texto legal, es natural que el Título I. Régimen Sancionador de las Entidades de Crédito, aluda a éstas "in genere" sin especificar el supuesto Cajas de Ahorro, así como el Título II. Ejercicio de las actividades y uso de denominaciones reservadas a las Entidades de Crédito, con ninguna especial referencia a la utilización del término "Cajas", aunque tal vez hubiese sido conveniente su precisión, si bien tampoco se hace en el supuesto de los "Bancos", por ser más genérica la referibilidad y más omnicomprensiva al no fijarse en concretas denominaciones, lo que también ocurre con el Título III. Medidas de intervención y sustitución, que comparte con las anteriores al redactarse en términos generales de referencia.

En el Título IV. Disposiciones complementarias, en el art. 39 de la Ley de Disciplina, donde al modificar el Real decreto legislativo 1298/1986, de 28 de junio, como hemos visto anteriormente, se da una definición de Entidades de Crédito y se conceptúa en particular Entidad de Crédito a las Cajas de Ahorros (59).

El art. 40, fundamental en el objeto e intención de este trabajo, se dedica a las cajas de Ahorros, en cuanto a la responsabilidad de las Comi-

(59) Vide, art. 39 de la Ley de Disciplina, donde se produce un ajuste terminológico, sustituyéndose la denominación "muy grave" del art. 57. 7 de la Ley de Ordenación de 1946, consistente en exclusión del Registro por la revocación de la autorización del establecimiento, en la actualidad Entidad, cambio obligado al ser aplicable esta sanción a las Cajas de Ahorros en virtud de la nueva redacción dada al art. 156 del Real Decreto 2532/1929, de 21 de noviembre, por el art. 4. 4 del Real Decreto legislativo $1298 / 1986$. 
siones de Control, extremo ya detectado y examinado en su lugar, pero por las especiales características, pues el acento e incidencia particular de las responsabilidades a que haya lugar se sitúa en las personas, miembros integrantes de estas Comisiones, se pasa de las personas jurídicas, sujetos pasivos en el ordenamiento del crédito $(60)$ a la persona física según mandato obligado de la Ley de Disciplina. No se van a significar la clasificación y tipificación de infracciones: muy graves, graves y leves.

Se debe sin embargo significar cuál es el nuevo sistema, en el tema de la responsabilidad, el cual funciona de forma coherente, pues se hace responder a las Comisiones de Control única y exclusivamente por el incumplimiento de sus deberes, relacionados con el fin que las justifica: la supervisión y el control y no, por supuesto, por lo actuado por otros responsables de la gestión, administración y dirección de las Cajas de Ahorros, lo cual supone responder por hechos propios y no ajenos (61).

La propia Ley de Disciplina sigue insistiendo en la ordenación, intervención y disciplina en el sector crediticio y por ende de sus Entidades, aludiendo de forma expresa a las Cajas de Ahorro ahora ya desde la competencia del Banco de España en relación con sus administrados cualificados, sujetos pasivos como son aquellas Instituciones. En este aspecto y comentario del art. 42, hemos hecho a nuestro entender las pertinentes observaciones, insistir ahora únicamente en el polémico tema, con detenimiento contemplado en la parte primera de este estudio, sobre reparto competencial en materia sancionadora, la de más relieve, en relación con las Cajas de Ahorros, ahora regulado, teniendo en cuenta además la jurisprudencia constitucional producida poco antes, en especial la Sentencia 49/1988, de 22 de marzo, examinada aquí con la suficiente extensión.

Una distribución que estimamos importante en este precepto del art. 42 de la Ley de Disciplina, es la determinación de preceptos básicos a los efectos del ejercicio de competencias en materia de Cajas de Ahorros y Cooperativas de Crédito (62) diferenciación estimada de artificiosa

(60) Vide, el art. 40. 1 de la Ley de Disciplina que taxativamente ordena: "Incurrirán en responsabilidad administrativa los miembros de las Comisiones de Control de las Cajas de Ahorros ..." subrayamos la personificación de dicha responsabilidad administrativa.

(61) Vide, sobre "Cajas de Ahorros" el reciente trabajo de José Eugenio Soriano García, en el vol. colectivo op. cit. "Estudios de Derecho Público Bancario", dirigido por Sebastián Martín Retortillo, Ceura, Madrid 1987 (págs. 390-419), con una interesante bibliografia, sobre todo histórica, a pie de página, en especial vide, el ap. II. "La problemática de la naturaleza de las Cajas" (págs. 406-419).

(62) Vide, en relación con este aspecto y materia los "Comentarios a la Ley de Disciplina e Intervención de las Entidades de Crédito", op. colectiva cit. , el comentario al art. 42 de José Luis Piñar Mañas, antes cit. ; en especial las págs. 135 y sgts. , ap. III. "La distribución de competencias en materia sancionadora respecto de las Cajas de Ahorros y Cooperativas de Crédito". 
por algún sector doctrinal, criterio del que disentimos pues diferenciar entre lo que son preceptos básicos al efecto de competencias en materia de Cajas de Ahorros y en materia sancionadora, diferenciar entre lo sustancial y lo adjetivo, a efectos de clarificación y seguridad jurídica no es baladí (63).

El tema de las Cajas de Ahorro en un momento determinado se convierte en monográfico para la Ley de Disciplina y las alusiones a esta voz son reiterativas, asi el art. 43.5 al salvar las competencias de las Comunidades Autónomas en lo dispuesto en la Ley sobre Organos Rectores de las cajas de Ahorros, Ley 31/1985, de 2 de agosto, antes examinada, ahí se hace expresa mención a estas Instituciones, como consecuencia de lo preceptuado por la disposición adicional primera num. 3, de la referida Ley de órganos Rectores (64).

En el régimen adicional y transitorio, pues la disposición derogatoria de la Ley de Disciplina no viene al caso, no hay alusiones concretas a la voz Cajas de Ahorro, aunque están presentes en la mayoría de los preceptos al citarse las Entidades de Crédito, que en especial son aquéllas, pero en este rápido repaso se ha intentado poner de manifiesto, patentizar, citas por su nombre y denominación a las $\mathrm{Ca}$ jas de ahorro y esto sólo se hace en una ocasión de forma expresa al regular el arrendamiento financiero en la disposición adicional séptima num. 10, en donde a partir de 1 de enero de 1990 se autoriza a Cajas de Ahorro y a la Confederación Española de Cajas de Ahorros, a desarrollar este tipo de operaciones, cumpliendo en todo caso las condiciones previstas en la Ley de Disciplina y en las disposiciones reglamentarias que desarrollen (65).

(63) Así opina Piñar Mañas, en su trabajo cit. nota anterior, pág. 135, segunda columna, antepenúltimo y último párrafos, y dice en relación con los apts. 1 y 7 del art. 42 de la Ley de Disciplina, "la diferenciación es un tanto artificiosa", lo subrayamos por ser expresión gráfica del autor.

(64)Vide, el art. 43. 5 de la Ley de Disciplina e Intervención que dice: "Lo dispuesto en este artículo se entiende sin perjuicio de las competencias que tengan atribuidas las Comunidades Autónomas y de lo que resulte de los Convenios entre el Banco de España y las Comunidades Autónomas a que se refiere la disposición adicional primera, número 3, de la Ley 31/1985, de 2 de agosto, sobre Organos Rectores de las Cajas de Ahorros".

(65) Vide, la disposición adicional séptima de la Ley de Disciplina que estipula en su núm. 10: "A partir de 1 de enero de 1990 las operaciones de arrendamiento financiero previstas en este_articulo...", se subraya pues no se trata de un artículo, sino de una disposición adicional, tal vez porque en el Proyecto de Ley figurase en el articulo y no como disposición transitoria. Los comentaristas de esta disposición no reparan ni hacen referencia a esta incidencia; Vide, el comentario cit. pág. 180, segunda columna, de José Luis Piñar Mañas al hacer una exégesis del punto 10 de esta disposición, sólo señala que los Bancos y Cajas de Ahorros que hasta utilizaban la técnica de crear sociedades "ad hoc" bajo su dependencia, para realizar estas operaciones, a partir de 1990 no será necesario. 
Después de este breve repaso a las indicaciones expresas de la Ley de Disciplina e Intervención de las Entidades de Crédito a las Cajas de Ahorro, se ha de finalizar con unas breves alusiones a los poderes normativos del Banco de España.

Una advertencia previa, después de las reiteradas alusiones a esta problemática, tan examinada y discutida doctrinalmente como hemos visto, lo cual aconsejaría aparcar por un tiempo el asunto, para obtener un sedimento necesario e imprescindible para la objetividad impuesta en éste y en otras cuestiones, lo suficientemente debatidas.

Es verdad y obvio, lo prolífico y fecundo en términos de opinión y discurso que tienen estos temas, la susceptible y delicada naturaleza del planteamientos de este tenor, las posturas próximas o antagónicas al respecto y lo fértil en discusión de entrar en matices y apreciaciones al respecto.

Una realidad se impone por encima de discusiones y apreciaciones doctrinales, la necesaria instrumentación de facultades y poderes públicos del Banco de España en relación con los intermediarios financieros. No puede aquél implementar medidas si no comunica, de ahí el nombre originario de Circular en sentido gramatical, a los destinatarios las órdenes coyunturales y oportunas para ejercitar las funciones y el papel a él atribuidos, por el régimen y ordenamiento jurídico vigente en el sector crediticio y de la intermediación financiera.

Deducción lógica es el número, quizás excesivo, de una normación menor en rango jurídico, pero importante y necesaria. Lo mejor es que una Ley de Funciones del Banco de España dejara, de una vez por todas, en su sitio este centro polémico, en ocasiones beligerante, para la necesaria pacificación de un desenvolvimiento sin incidencias, soporte necesario en pro de una eficaz tarea, muy técnica de otra parte, profesionalizada y tan sensible que necesita de respuestas inmediatas, más que de consideraciones y elucubraciones sobre garantías formales, o adecuación a un sistema, adecuada y normal desiderata hace años pero hoy obsoleto.

Lo hemos dicho e insistimos el riesgo de convertir en bizantina la especulación al respecto, por obligado cumplimiento nos hemos hecho cuestión y eco del estado doctrinal y de opinión, pero intimamente convencidos de la esterilidad de un esfuerzo en intento de someter a formalidades de publicidad de un esfuerzo en intento de someter a formalidades de publicidad, a referencias de poderes originarios o no, a utilización correcta o superación de delegaciones o atribuciones, incluso a remisiones en blanco, a convalidaciones o consagraciones posteriores, a dar carta de naturaleza legal a actuaciones sino ilegales fronterizas. 
Existen elementos indudables en nuestro ordenamiento para habilitar al Banco de España y que éste pueda ejercer sus funciones públicas, por un cauce normativo, pues no hay hasta la fecha otro camino, existe por otra parte un asentimiento casi complacencia de los destinatarios, consciente de que para funcionar en orden necesitan ser ordenados, entonces la discusión es exógena, con prurito frecuente de formalizar relaciones cordiales hasta hoy, no analizamos por qué, pero si se inquietan por estos prejuicios, a veces evidentes en pura técnica jurídica, se hace un flaco servicio a la ordenación y sectorialmente a la materia y a los agentes que de ella entienden.

Nada más lejos de nuestra intención de llegar a una situación arbitrista en sentido peyorativo del término, pero sí de arbitrar, mediante el arbitrio que es sólo instrumento adiáforo, unas relaciones en ocasiones tensas, como es el binomio Banco de España/Ministerio de Economia y Hacienda y su reformulación actual, también en cierto grado conflictivo Banco de España/Comunidades Autónomas, pero no en flexión conflictual sino distendida, en este caso Banco de España/Cajas y Confederación Española de Cajas de Ahorros.

Es decir, estimamos necesario un deslinde y amojonamiento de la parcela, con pocas pero claras instrucciones, con un límite en su caso limitaciones, con medidas que comprimen pero no suprimen un ejercicio funcional, desde el principio necesario.

Con estas breves indicaciones, presupuestos e hipótesis eludimos conscientemente las posibles evaluaciones y en términos de practicidad reenviamos el tema a su ejecución, en pacífico y ordenado desarrollo.

Para finalizar no podemos olvidar la máxima aparentemente trivial, pero cierta, de que derecho es lo que se vive y no lo que se escribe, por tanto la regulación proveniente del Banco de España, con su proliferación excesiva, con su falta de técnica formal, con su variabilidad y constante modificación, con un sistema continuo e ínsito de derogaciones, revisiones, actualizaciones, etc. , nos conducen a un mundo de vivencias y existencias reales, no por olvidadas o no atendidas menos actuales y ciertas. Si se permite el barbarismo el derecho emanado del Banco Central, centra la actividad de las Entidades que tutela, protege, interviene, controla y supervisa, con una vitalidad que supera cualquier otra consideración ajena. 


\section{CRONICAS}

REALA-1991, núm. 251. CARRASCO CANALS, CARLOS. COMPETENCIAS SOBRE CAJAS DE AHORR... 
